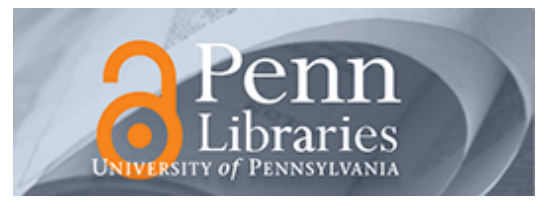

University of Pennsylvania

ScholarlyCommons

Accounting Papers

Wharton Faculty Research

2-2010

\title{
How Does Internal Control Regulation Affect Financial Reporting?
}

Jennifer M. Altamuro

University of Pennsylvania

Anne Beatty

Follow this and additional works at: https://repository.upenn.edu/accounting_papers

Part of the Accounting Commons

Recommended Citation

Altamuro, J. M., \& Beatty, A. (2010). How Does Internal Control Regulation Affect Financial Reporting?. Journal of Accounting and Economics, 49 (1-2), 58-74. http://dx.doi.org/10.1016/j.jacceco.2009.07.002

This paper is posted at ScholarlyCommons. https://repository.upenn.edu/accounting_papers/112

For more information, please contact repository@pobox.upenn.edu. 


\title{
How Does Internal Control Regulation Affect Financial Reporting?
}

\begin{abstract}
Internal control regulation effectiveness remains controversial given the recent financial crisis. To address this issue we examine the financial reporting effects of the Federal Depository Insurance Corporation Improvement Act (FDICIA) internal control provisions. Exemptions from these provisions for banks with assets under $\$ 500$ million and for non-US banks provides two unaffected control samples. Our difference-in-differences method suggests that FDICIA-mandated internal control requirements increased loan-loss provision validity, earnings persistence and cash-flow predictability and reduced benchmarkbeating and accounting conservatism for affected versus unaffected banks. More pronounced effects in interim versus fourth quarters suggest that greater auditor presence substitutes for internal control regulation.
\end{abstract}

\section{Keywords}

internal controls, financial reporting quality, FDICIA, loan-loss provision, reporting discretion

Disciplines

Accounting 


\title{
How Does Internal Control Regulation Affect Financial Reporting?
}

\author{
Jennifer Altamuro \\ altamuro.1@,osu.edu, 614-688-8679 \\ Fisher College of Business \\ The Ohio State University \\ 448 Fisher Hall \\ 2100 Neil Avenue \\ Columbus, OH 43210 \\ Anne Beatty* \\ beatty.86@osu.edu, 614-292-5418 \\ Fisher College of Business \\ The Ohio State University \\ 442 Fisher Hall \\ 2100 Neil Avenue \\ Columbus, OH 43210
}

\begin{abstract}
Internal control regulation effectiveness remains controversial given the recent financial crisis. To address this issue we examine the financial reporting effects of the Federal Depository Insurance Corporation Improvement Act (FDICIA) internal control provisions. Exemptions from these provisions for banks with assets under $\$ 500$ million and for non-U.S. banks provides two unaffected control samples. Our difference-indifferences method suggests that FDICIA-mandated internal control requirements increased loan-loss provision validity, earnings persistence and cash-flow predictability, and reduced benchmark-beating and accounting conservatism for affected versus unaffected banks. More pronounced effects in interim versus fourth quarters suggests that greater auditor presence substitutes for internal control regulation.
\end{abstract}

*Corresponding author. Beatty thanks Deloitte \& Touche, for financial support. We would like to thank Bob Holthausen (the editor), Phil Berger, Jeff Callen, Rick Johnston, Ryan Lafond (the referee and discussant) Luanne Lynch, Doug Schroeder, Mary Stanford, Rick Young, Pete Wilson, Arnie Wright, Helen Zhang and seminar participants at Boston College, University of Houston, London Business School, The Journal of Accounting and Economics Conference, Michigan State, The Midwest Summer Research Conference, The Ohio State University, The University of Oklahoma Ethics Conference, The University of Southern California and The Toronto Accounting Research Conference for their helpful comments and suggestions. 


\section{Introduction}

Internal control systems have long been advocated as a mechanism for establishing high quality financial reporting, and firms have voluntarily used them for this purpose. In response to several high-profile financial frauds, the Committee of Sponsoring Organizations of the Treadway Commission (COSO) issued their Internal Control Integrated Framework in September 1992. This report provided a foundation for assessing internal control effectiveness. Since then, several waves of accounting scandals have led to regulatory requirements for managers and auditors to report on internal control effectiveness. Most recently, the Sarbanes Oxley Act (SOX) internal control provisions have fueled the ongoing debate among regulators and practitioners about the effectiveness of this type of regulation in improving financial reporting quality given the subsequent financial crisis. In a speech delivered at the U.S. Chamber of Commerce Global Capital Markets Summit, James Turley (2008), Chairman and CEO of Ernst \& Young, calls for "a global debate about what management should be saying about its controls, (and) what auditors should be saying about them, if anything."

Supporters of internal controls regulation argue that limiting managerial discretion improves financial reporting quality. While potentially true for firms with material internal control weaknesses, limiting managerial discretion may not improve financial reporting, on average, for all regulated firms and could potentially reduce financial reporting informativeness. For example, Bagnoli and Watts (2005) show that managers with discretion to report conservatively can signal their private information about the probability of good future prospects. Essential to resolving this argument is the ability to 
isolate changes in financial reporting due to internal controls regulation. In their study evaluating the effectiveness of SOX internal controls regulation, Hochberg et al. (2009) point out that "the central challenge to distinguishing between the two main views ... is the lack of a control group of ... firms unaffected by the legislation.”

The internal control provisions of the Federal Deposit Insurance Corporation Improvement Act of 1992 (FDICIA) facilitate meeting this "control group" challenge by exempting some firms from these provisions. In the absence of an explicit exclusion, the FDICIA provisions apply to all insured depository institutions. ${ }^{1}$ Such an exclusion exists for the FDICIA internal control provisions, in contrast to all other FDICIA provisions. FDICIA exempts institutions with assets less than $\$ 500$ million from its internal control monitoring and reporting requirements. Specifically, these institutions are exempted from FDICIA's requirements that management issue a report on the effectiveness of internal controls over financial reporting, and that their independent public accountant attest to management's report. This exemption provides a control group unaffected by the internal control legislation, but otherwise similarly affected by the remaining FDICIA provisions. We examine the relative impact of this regulatory shift in internal control systems monitoring on financial reporting quality for the average affected versus unaffected firm.

We compare annual and quarterly financial reporting of bank holding companies (banks) affected by FDICIA's internal control provisions to that of unaffected banks. Specifically, we examine changes in: the validity of the loan loss provision, earnings quality, benchmark-beating, and accounting conservatism. We analyze two samples, (1) a

\footnotetext{
${ }^{1}$ While FDICIA regulations did bring Savings and Loans (S\&Ls) under the auspices of the FDIC, this study examines the impact of FDICIA-mandated internal control provisions on commercial banks.
} 
sample of U.S. public and private banks included in the Fed Form Y9-C Regulatory Filing database and (2) a sample of publicly-traded banks included in the COMPUSTAT database. ${ }^{2}$ Our difference-in-differences research design isolates the effects of the FDICIA internal controls provision by controlling for changes in financial reporting unrelated to those provisions. We validate our control samples by testing for differences between the affected and unaffected firms in the pre-regulation period.

We argue that in addition to providing a control sample, our setting has several advantages for examining how internal controls regulation affects financial reporting. First, the effective date of FDICIA enables a long-range study of the impact of the first regulatory enforcement of COSO-based internal control provisions, which have served as the cornerstone of future regulation. The relationship between FDICIA and SOX internal control reforms has been well documented, with Securities and Exchange Commission (SEC) Chairman Cox (2007) declaring that "FDICIA was a 'clear antecedent' to the SOX internal control reforms." Second, focusing on a single industry allows us to isolate and examine changes in the validity of the account most likely affected by internal control deficiencies, the loan-loss provision, and to explore how account-specific changes lead to more general changes in financial reporting. Third, our examination of all firms affected by the regulation, rather than only those most likely to benefit from the regulation (i.e. those with material internal control weaknesses), allows us to make an unbiased assessment of the financial reporting impact of the regulation on all affected firms. Finally, our comparison of the interim quarters to the fourth quarter allows us to assess whether the extent of auditor presence substitutes for internal controls regulation.

\footnotetext{
${ }^{2}$ Although FDICIA applies at both the bank and holding company levels, we focus on holding companies to increase comparability between our Regulatory and COMPUSTAT analyses.
} 
We compare the change in financial reporting for our affected and control firms in the seven-year periods before and after the passage of FDICIA. First we examine the properties of the annual financial reports. We find that the FDICIA-mandated internal control requirements lead to improvements in the validity of the loan-loss provision. Specifically, the association between the loan-loss provision and actual loans written off for affected banks strengthened in the period after the enactment of FDICIA. This improvement addresses the GAO's (1994) concern “that banks' loan-loss allowances included large supplemental reserves that were not linked to analysis of loss exposure or supported by evidence." We find a corresponding increase in both earnings' persistence and ability to predict cash flows, and a reduction in the use of earnings management to report positive earnings growth, suggesting that reducing supplemental reserves generally improves reporting quality. However, we also find that earnings conservatism declines for affected versus unaffected banks in both samples. This reduction in conservatism is also consistent with a reduction in supplemental reserves.

Next we examine the properties of quarterly reports to determine whether the effects are larger in the interim quarters relative to the fourth quarter, when an increased auditor presence might substitute for improved internal controls. Consistent with this hypothesis, we find that the improvements in the validity of the loan loss provision, and the increase in earnings persistence and predictability of future cash flows, are all larger in the first three quarters than in the fourth quarter.

Taken together, these results suggest that the FDICIA-mandated internal control provisions resulted in the average bank exercising less reporting discretion. This reduced discretion creates a greater association between current reported accrual numbers and 
future cash flow numbers. However, as a result of this improved association, the reported accrual numbers also became less conservative. Thus, the conclusion about how this regulation affected the quality of financial reports depends on one's definition of quality. Our results suggest improved reporting quality based on the FASB's argument in Statements of Financial Accounting Concepts (SFAC) 2 that "conservatism in financial reporting ... [i.e.] any attempt to understate results consistently is likely to raise questions about the reliability and integrity of the information about those results." However, Watts' (2003) argument that the "attempts to ban conservatism ... are likely to fail and produce unintended consequences" suggest that the changes in financial reporting characteristics that we document may indicate a deterioration, rather than an improvement, in financial reporting quality.

We believe our results can inform the debate between regulators and practitioners over the merits of internal controls regulation. Our focus on banks is particularly relevant to the renewed debate over this type of regulation arising from the recent financial crisis. In addition, our study can be used to draw inferences about the implications of similar changes in internal control regulations outside of the banking industry, in particular for regulations that are also based on the COSO framework, such as the SOX internal control provisions. Thus, we believe that our results could have broad implications for understanding the effects of internal control regulations.

Section 2 provides the background for our study. We discuss hypotheses in Section 3; sample selection in Section 4 and research design in Section 5. We present our results in Section 6 and discuss our sensitivity test results in section 7. We conclude in Section 8 . 


\section{Background}

2.1 Development of Internal Control Regulation in the U.S.

\subsubsection{COSO}

COSO is a private-sector initiative begun in 1985 to address fundamental causes of financial reporting scandals. Reliability of financial reporting is one of the three objectives of the internal control process in the COSO framework. The COSO Report provides guidelines for assessing effective control system attributes, and states that: internal control is broadly defined as a process, affected by an entity's board of directors, management and other personnel, designed to provide reasonable assurance regarding achievement of effectiveness and efficiency of operations, reliable financial reporting, and compliance with applicable laws and regulations. ${ }^{3}$

In an October, 2006, speech, Charles D. Niemeier, a Public Company Accounting Oversight Board (PCAOB) member, states that:

Although U.S. companies have been required to have internal controls over their accounting since Congress enacted the Foreign Corrupt Practices Act of 1977, by the 1990s many corporations had still failed to establish or maintain effective controls ... that would ensure integrity in the preparation of the overall financial statements. ... This lack of internal controls allowed senior corporate managers to manipulate official reported financial results to look better than they were... In the early 1990s, Congress attempted to bolster controls in the banking sector at least, by requiring in ... FDICIA that certain financial institutions provide banking regulators with assessments of, and auditor attestations on, their internal controls.

\subsubsection{FDICIA}

FDICIA was enacted to change federal oversight of depository institutions, and as a result, four new sections were added to the Federal Deposit Insurance Act (The Act). The Act applies to all depository institutions that are insured by the Federal Deposit Insurance Corporation (FDIC), unless an explicit exemption is made for a particular section of The Act. Of these four sections, only Section 36 entitled "Early Identification

\footnotetext{
${ }^{3}$ http://www.coso.org/key.htm
} 
of Needed Improvements in Financial Management," includes such an exemption. Specifically, this section includes an exemption for institutions with total assets less than the greater of $\$ 150$ million, or a larger amount prescribed by regulation. On June 2, 1993, the FDIC issued such a regulation, increasing this exemption to cover banks with assets less than $\$ 500$ million [GAO (1996)]. This exclusion was allowed for economic efficiency reasons (Murphy, 2004). Consequently, only U.S. banks with assets greater than $\$ 500$ million are subject to the internal controls provision of FDICIA.

Section 36 requires that banks establish an independent audit committee, and that they report annually on "Management Responsibility for Financial Statements and Internal Controls" and "Internal Control Evaluation and Reporting Requirements for Independent Public Accountants." The management responsibility report must be signed by the CEO and the chief accounting or financial officer. The report must state management's responsibilities for preparing financial statements, establishing and maintaining an adequate internal control structure and developing procedures for financial reporting and complying with related laws and regulations. The report must also provide an assessment of the effectiveness of the internal control structure and procedures, and the institution's compliance with laws and regulations relating to safety and soundness as of the end of the fiscal year. The report of the independent public accountant must include an attestation to the assertions of management included in the management report. This annual report also requires an independent audit of the financial statements (conducted in accordance with GAAS). ${ }^{4}$

\footnotetext{
${ }^{4}$ Our study focuses on the comprehensive effects of the regulation. We do not attempt to isolate which component of Section 36 may be responsible for changes in the financial reporting environment.
} 
The other three sections that FDICIA added to The Act apply to all federally insured depository institutions regardless of size. Section 37 "Accounting Objectives, Standards and Requirements" requires that regulatory accounting be at least as stringent as GAAP, and that all federal banking agencies maintain uniform accounting standards when determining statutory or regulatory compliance. Section 38 "Prompt Corrective Action," requires that regulators classify depository institutions into one of five capital adequacy categories, including three undercapitalized categories, based on the severity of undercapitalization. The section requires regulators to take 1 or more of 10 specified actions against institutions in these categories. Section 39 "Standards for Safety and Soundness," requires regulators to establish safety and soundness standards related to operations and management, asset quality, earnings and stock valuation and compensation. ${ }^{5}$

\subsubsection{Internal Controls and the Loan Loss Provision}

The idea that internal control regulation could improve financial reporting reliability is supported by the GAO's (1991) report to Congress on banking failures. The GAO argued that for the failed banks examined "the external reports were distorted by internal control problems." In a subsequent report to Congress focusing exclusively on loan-loss accounting, the GAO (1994) argued that banks' loan loss allowances included large supplemental reserves that were not linked to analysis of loss exposure or supported by evidence. The report states that "use of unjustified supplemental reserves can conceal

\footnotetext{
${ }^{5}$ The GAO (1996) report provides an excellent summary of these Sections of The Act. Since these Sections applied to all firms regardless of size, it appears that FDCIA intended consistent application of these regulations to all regulated banks. If these provisions led to financial reporting improvements for all banks, this would bias against our finding differential results for our test and control banks consistent with the internal controls provisions (Section 36). However, if bank examiners applied the mandates of Sections 38 and 39 more stringently to larger banks, this could confound the interpretation of our results.
} 
critical changes in the quality of an institution's loan portfolio and undermine the credibility of financial reports." The internal control regulation implemented in FDICIA was designed to improve financial reporting, at least in part, by reducing managers' ability to create supplemental reserves.

\subsubsection{Internal Control Regulations in the $21^{\text {st }}$ Century}

The widely-publicized 1999-2001 accounting scandals prompted regulators to once again consider additional internal controls regulations to restore public confidence in financial markets. Building directly on the FDICIA implementation of the COSO framework, Congress passed SOX in July, 2002. The most extensive provisions relate to internal control system monitoring and reporting. Section 302 requires that management assess internal control system validity and notify the board of directors and auditors about any internal control weaknesses, while Section 404 explicitly requires management to report annually on internal control system adequacy, and independent auditors to attest to management's assessment. Figure 1 outlines the relationship between the FDICIA internal control regulations, and the subsequent SOX provisions.

The current financial crisis has reenergized the internal control regulation debate with some arguing for increased regulation while others argue that the failure of existing regulation to prevent this crisis suggests the futility of additional regulation. In her confirmation hearings Mary Shapiro, subsequently sworn in as SEC Chairman, stated that:

...Accurate, robust, and easy-to-understand financial reporting -- and the internal controls that guarantee it -- are critically important to investors and to the efficient functioning of our markets. Right now, we have a system where some issuers are complying with 404 and others are still exempt from it. It's time that we bring uniformity to the system so that investors know what to expect from companies... 
In contrast, in comments made about the government bailout plan in September, 2008,

Mike Huckabee, former Arkansas Governor and Republican presidential candidate stated:

If Congress wants to do something, here are some suggestions: .... Repeal

Sarbanes/Oxley. It has failed. It was supposed to prevent this. It didn't. Kill it.

Smith (2003) provides an intermediate view pointing out that:

Only government would even purport to pursue the Utopian goal of eliminating risk... risks are ubiquitous - any decision increases some risks and reduces others; therefore, the question of balance is critical.

The response to the financial crisis suggests that when assessing how internal controls regulation affects financial reporting, it is important to consider all regulated firms, not just those with material weaknesses, and to understand that eliminating all bad outcomes cannot be the goal of regulation or the benchmark by which regulation is judged. ${ }^{6}$

\subsection{Internal Controls Related Research}

Several studies suggest that FDICIA may have strengthened the economic viability of banks, however, this research has not examined whether the internal control provisions affect the quality of financial reporting. ${ }^{7}$ In contrast, SOX internal control provisions have been studied extensively. Papers examining firms with internal control deficiencies, including Doyle et al. (2007) and Ashbaugh-Skaife et al. (2007), find that these firms are weaker financially, more complex, growing rapidly, or restructuring, and have noisier accruals that do not map as well into cash flows. Ashbaugh-Skaife et al. (2008) find that earnings' properties improve subsequent to the disclosure of ineffective internal controls remediation. However, after controlling for primitive firm

\footnotetext{
${ }^{6}$ Given this argument, the fact that some banks reported internal control weaknesses under SOX does not provide evidence that FDICIA was inadequate.

${ }^{7}$ A Treasury Department report indicates that banks' ROA and ROE doubled between 1991 and 1996 (Carnell, 1997), while Benston and Kaufman (1998) conclude that FDICIA led banks to become more risk adverse, and less prone to failures.
} 
characteristics, Ogneva et al. (2007) fail to find cost of capital increases for firms with internal controls weaknesses. These analyses do not consider all regulated firms.

Zhang (2007) finds a significantly negative market reaction to SOX events, with the combination of restrictions on non-audit services, required corporate governance enhancements, and Section 404 mandates being costly for the overall market. Cohen et al. (2008) find an overall decline in accruals-based earnings management following SOX, but find real earnings management increases. The authors acknowledge that "whether this decline is caused by the passage of SOX... cannot be inferred from this analysis." ${ }^{8}$

In his review of the SOX literature, Coates (2007) states that "the law's full costs are hard to quantify, and the benefits even harder, so any honest assessment of Sarbanes-Oxley must be tentative and qualitative." Hochberg et al. (2009) review the SOX-related literature and discuss the difficulties associated with drawing conclusions without a control sample of firms unaffected by the legislation.

\section{Hypothesis Development}

We focus on the effect of regulation on average for all affected firms. We argue that when assessing internal controls regulation it is important to study all affected firms, not just those reporting material weaknesses or deficiencies in their internal controls. This argument is consistent with Smith's (2003) statement that the benefits of mitigating the risks imposed on the market by those with materially weak internal controls should be carefully weighed against the costs (both direct and indirect) of regulation borne by those whose deficiencies are less severe.

\footnotetext{
${ }^{8}$ Cohen et al. (2008) explicitly state that the nature of their study does not provide conclusive evidence whether the decline in earnings management observed post-SOX was caused by SOX, public response to scandals, or other concurrent events.
} 
Since we focus on a single industry, we are able to isolate and examine the account most likely to suffer from internal control problems, as well as explore how account-specific changes lead to changes in broader financial reporting measures. We focus on the loan loss provision, which was identified by the GAO (1991 and 1994) as the account most affected by internal control weaknesses and is typically a bank's largest operating accrual. We then examine more comprehensive financial reporting measures, specifically, earnings persistence and the ability of earnings to predict future cash flows. While not entirely independent constructs, we believe these two measures are distinct because our predictability measure should not be influenced by the use of the loan loss provision to smooth earnings. To further rule out the smoothing hypothesis, we examine the effect of the FDICIA internal control provisions on beating a small positive earnings benchmark. We also acknowledge that reduced discretion may limit managers' ability to convey private information, leading to decreased conservatism. Consequently, we examine how conservatism changes in the pre- to post-period for the affected versus unaffected firms. These more comprehensive financial reporting measures also generalize outside the banking industry and provide insights about the potential impact of other comprehensive internal controls regulations, such as the SOX provisions. ${ }^{9}$

In July of 2001, the SEC issued Staff Accounting Bulletin (SAB) 102 which provides the SEC staffs' guidance for validating the method used to estimate the loan losses. SAB 102 states that:

the staff believes that a registrant's loan loss allowance methodology is considered valid when it ... include(s) procedures that adjust loan loss estimation methods to reduce differences between estimated losses and actual subsequent charge-offs.

\footnotetext{
${ }^{9}$ See Francis et al. (2004) and Wysoki (2005) for further discussion of these financial reporting metrics.
} 
If the changes in internal control monitoring improve the measurement of operating activities, then we expect FDICA to lead to a stronger association between the loan loss provision and next period charge-offs for affected banks. Although finding an increased association between the loan loss provision and future charge-offs might suggest enhanced loan-loss provision validity, it would not necessarily imply that aggregate financial reporting has improved.

However, if the GAO (1991) is correct that external reports were distorted by loan-loss internal control problems, then we would expect the improvements in loan-loss provision validity to lead to aggregate improvements in financial reporting. Specifically, given the importance of the provision in determining reported earnings, we would expect to see improvements in earnings quality.

Our first earnings quality measure is earnings persistence. Both Dechow and Dichev (2002) and Wysocki (2005) use this measure to test the validity of "accounting quality" models. Based on their arguments, we expect earnings persistence to increase for affected banks in the post-FDICIA period if the regulation worked as intended. However, other papers, such as Leuz et al. (2003) argue that increased earnings persistence may reflect earnings smoothing indicating lower rather than higher financial reporting quality. Higher earnings persistence could result from loan loss provision smoothing, which would not necessarily imply higher financial reporting quality.

To address this possibility, we consider a second earnings quality measure used by Wysocki (2005), which is the ability of earnings to predict future cash flows. Consistent with previous bank earnings quality research (Wahlen,1994, Kanagaretnam et al., 2004,), we measure cash flows by adding the loan loss provision to earnings before 
taxes. ${ }^{10}$ The persistence of the provision should not affect this cash flow measure, so we believe a separate examination of this measure provides additional insights despite the relatively high correlation between this measure and earnings. By looking at earnings before the provision, we are able to identify whether the effects of the FDICIA internal control provisions extend beyond the loan-loss provision. We expect an increase in the coefficient on our earnings variable in the post-FDICIA period for affected banks, if the FDICIA-mandated internal control provisions improve the quality of financial reports.

We further address the possibility that increased persistence is attributable to smoothing by examining how the FDICIA internal control provisions affect benchmark beating. Specifically, we examine the effect on small positive earnings changes. If increased persistence is driven by increased smoothing, which Liu and Ryan (2006) contend occurred during our sample period, then we would expect to find increases in this type of benchmark beating for affected banks. Alternatively, if FDICIA improves operating activity measurement, and banks were using loan-loss provision discretion to avoid missing benchmarks prior to the regulation, then we predict a decrease in benchmark beating for affected firms. We test these alternatives by examining changes in the incidence of this benchmark-beating activity.

While internal controls regulation could improve financial reporting, it is also possible that reducing discretion could have unintended consequences. We consider the possibility that the "unjustified supplemental reserves" described by the GAO, instead reflect justifiable accounting conservatism. Standard \& Poors (2002) argues in favor of

\footnotetext{
${ }^{10}$ Although our cash flow and earnings measures are highly correlated (74\% Pearson correlation) given that they differ only in the inclusion of the loan-loss provision, incorporating depreciation expense, or estimated accrued interest revenue leaves the correlation virtually unchanged.
} 
conservatism in loan loss accounting "given the dangers of underestimating the extent of impaired assets." We test for this possibility using the conservatism measure employed by Ball and Shivakumar (2005). We examine whether the association between earnings changes and lagged negative earnings changes was altered for affected banks. A positive change would indicate a decrease in accounting conservatism.

We further expect that the financial reporting effect of internal control regulations may differ by quarter, based on Mendenhall and Nichols' (1988) argument that "the quarterly reporting process provides managers with more discretion over interim-period cost formulations than is available at fiscal year-end" and the evidence in Boyd, Daley, and Runkle (1994) that these results apply to the loan loss provision in banks. We examine whether changes in loan-loss provision validity, earnings' persistence and predictability of future cash flows, benchmark beating and financial reporting conservatism differ in the fourth versus interim quarters for affected banks.

\section{Sample}

FDICIA went into effect during 1993. While FDICIA generally applied to all U.S. insured depository institutions, FDICIA's internal control provisions applied only to those with assets exceeding $\$ 500$ million, allowing us to identify two distinct control samples of unaffected banks. The first is U.S. banks with assets below $\$ 500$ million. The second is international banks that file U.S. GAAP reports but are not subject to FDICIA.

We draw bank financial data from two sources. The Fed Form Y9-C Regulatory Filing database provides the most extensive sample, including both publicly-traded and privately-owned U.S. banks. Our Regulatory sample comes from this database. Annual financial data reconciled to U.S. GAAP for international banks is available on the 
COMPUSTAT database if the bank trades American Depository Receipts (ADRs) on a

U.S. exchange. ${ }^{11}$ Our Compustat sample comes from this database. Although limited to publicly traded firms, this sample allows us to compare affected banks to two distinct groups of unaffected banks. Since quarterly data is unavailable for ADR firms, our quarterly analysis is limited to the regulatory sample. We eliminate observations if the banks' affected status changed during the period. ${ }^{12}$

We identify 16,191 U.S. bank-years and 67,232 U.S. bank-quarters with available Y9-C data and 4,401 bank-years with available COMPUSTAT data. We classify all observations from 1986-1992 as the pre-FDICIA period, and all observations from 19952001 as the post-FDICIA period. We omit observations during 1993-1994 from our analyses because this is the implementation period. ${ }^{13}$

\section{Research Design}

We use a difference-in-differences research design to mitigate concerns that our results are driven by other changes during the period, such as changes in general economic conditions or changes in regulation - including the other changes required by FDICIA that affected all U.S. banks. We use two control groups, one with unaffected banks smaller than the affected banks and one with unaffected banks larger than the

\footnotetext{
${ }^{11}$ To maximize sample size; we do not restrict our sample to ADRs filing full U.S. GAAP financial statements. While all earnings are reported under U.S. GAAP, certain other accounts (i.e. assets) may be determined using the home country GAAP. Our difference-in-differences research design mitigates the impact of this issue, and we perform sensitivity tests on capital structure differences across countries. 12 Although it might be interesting to study firms that change affected status during the post regulatory period, the 9 banks with assets above 500 million that subsequently fall below the regulatory threshold provide insufficient observations to analyze. We also think that the 364 unaffected banks that subsequently exceed the $\$ 500$ million threshold, representing less than $10 \%$ of our sample, provides too small a sample to study. We have chosen to omit these banks entirely, but including them does not change our results.

${ }^{13}$ We study all observations with available data in either the pre- or post-regulatory period, since examining a constant sample would impose a severe sample selection bias. We discuss the entrance and exit rates for our test and control samples in our sensitivity analysis section.
} 
affected banks, to alleviate concerns that any differences documented in the change in earnings properties are caused by differential effects of economic changes on our test and control samples.

Our primary analyses compares changes in financial reporting for affected relative to unaffected banks in the post versus pre-FDICIA periods. For our Regulatory sample, we use two indicator variables to conduct these tests. $500 \mathrm{M}$ is an indicator variable that equals one if the firm has Total Assets less than $\$ 500$ million (the FDICIA internal control provision threshold) at both the beginning and the end of year t, zero otherwise, and Post is an indicator variable that equals one in the post-FDICIA period (after 1992), zero otherwise. These variables serve as off-sets to our main variable of interest in each regression, allowing us to isolate the impact of the FDICIA internal control provisions on financial reporting.

In our Compustat sample, we include the variable ADR, an indicator variable that equals one for non-U.S. banks with ADRs in the U.S. market, zero otherwise. Since all of the ADR banks in this sample are larger than $\$ 2$ billion in assets, we cannot interact our $500 \mathrm{M}$ and ADR indicator variables. All of the ADR banks would be considered affected banks based on size, but serve as control firms because non-U.S. banks are not subject to FDICIA regulations. ${ }^{14}$ We interact ADR with Post and our variables of interest in each regression to measure the impact of FDICIA on affected firms.

Our 500M and ADR variables also allow us to examine whether there are differences in our affected and control samples in the period prior to the regulation.

\footnotetext{
${ }^{14}$ The ADR banks are not subject to any of the FDICIA regulations. To the extent that the prompt corrective action provisions (Sections 38 and 39) of FDICIA affected financial reporting, the ADRs will serve as a less complete control sample than do the U.S. banks with assets less than $\$ 500$ million.
} 
Failure to document significance when these variables are interacted with our variables of interest supports the appropriateness of our control samples.

We choose to examine a fourteen-year window surrounding the enactment of FDICIA for several reasons. Mishkin (1996) points out that as of 1996 "FDICIA has never really been tested" because a true test of the regulation requires variation in the economic conditions. His comments indicate that FDICIA's effects could not truly be tested using a single year of data, and that a longer testing period is desirable because it increases the variety of economic conditions. We end our sample period in 2001 for two reasons. First, we wanted symmetric pre- and post-regulation periods. Given that the Y9C data began in 1986, this limited us to seven years of data prior to the regulation.

Second, by limiting our sample to years prior to 2002, we eliminate concerns about the potentially confounding affects of the SOX regulation.

Petersen (2009) shows that correlation in residuals across firms or time in panel data studies of financial data cause bias in OLS standard errors. Consequently, we use a generalized linear model to control for potential data clustering in all of our analyses.

\subsection{Annual Analyses}

\subsubsection{Relationship between the Provision for Loan Losses and Loan Charge-offs}

If FDICIA-mandated internal control requirements improve loan-loss provision validity, we should find a larger association between current period loan-loss provision and next period charge-offs. We estimate the following model using both our Regulatory and Compustat samples:

(1) $\mathrm{CHGOFF}_{\mathrm{t}+1}=\alpha+\beta_{1}$ Post $+\beta_{2} 500 \mathrm{M}_{\mathrm{t}}+\beta_{3}$ Post $^{*} 500 \mathrm{M}_{\mathrm{t}}+\beta_{4} \mathrm{LLP}_{\mathrm{t}}+\beta_{5}$ Post $^{*}$ LLP $_{\mathrm{t}}$ $+\beta_{6} 500 \mathrm{M}_{\mathrm{t}} * \mathrm{LLP}_{\mathrm{t}}+\beta_{7}$ Post $^{*} 500 \mathrm{M}_{\mathrm{t}} * \mathrm{LLP}_{\mathrm{t}}+\beta_{8}$ Size $_{\mathrm{t}}+\beta_{9}$ Size $_{\mathrm{t}} * \mathrm{LLP}_{\mathrm{t}}$ $+\beta_{10}$ Nonacc $_{\mathrm{t}}+\beta_{11}$ ADR $+\beta_{12}$ Post $^{*}$ ADR $+\beta_{13}$ ADR $^{*}$ LLP $_{\mathrm{t}}$ $+\beta_{14}$ ADR $^{*}$ Post $^{*}$ LLP $_{\mathrm{t}}+\mathrm{e}$ 
Where:

$\mathrm{CHGOFF}_{\mathrm{t}+1}-$ Loan charge-offs during year $\mathrm{t}+1$, scaled by beginning Total Assets;

$\mathrm{LLP}_{\mathrm{t}} \quad-$ Loan-loss provision during year $\mathrm{t}$, scaled by beginning Total Assets;

Post - An indicator variable that equals one in the post-FDICIA period (after 1992), zero otherwise;

$500 \mathrm{M}_{\mathrm{t}}-$ An indicator variable that equals one if Total Assets $>\$ 500$ million (the FDICIA internal control provision threshold) at both the beginning and end of year $\mathrm{t}$, zero otherwise;

Size $_{\mathrm{t}} \quad-$ The Log of Total Assets in millions at the beginning of year $\mathrm{t}$;

Nonacc $_{t} \quad-$ Non-performing at then end of year $t$, scaled by beginning Total Assets ;

ADR - An indicator variable that equals one for non-U.S. banks with ADRs, zero otherwise.

\subsubsection{Earnings Persistence and Predictability of Cash Flows}

We examine two related but distinct measures of earnings quality: persistence, and the ability of earnings to predict future cash flows. Persistence is defined as the coefficient on current period pre-tax earnings in a regression of future pre-tax earnings $\left(\mathrm{ROA}_{t+1}\right)$ on current pre-tax earnings $\left(\mathrm{ROA}_{t}\right)$. We assess earnings' ability to predict future cash flows $\left(\mathrm{EBP}_{\mathrm{t}+1}\right)$ using a regression of one period ahead pre-tax earnings before the loan-loss provision on current period pre-tax earnings $\left(\mathrm{ROA}_{t}\right)$. To investigate the effect of FDICIA-mandated internal control requirements on these related earnings quality measures, we estimate the following regressions separately for our Regulatory sample and our Compustat sample: ${ }^{15}$

(2) $\mathrm{ROA}_{t+1}$ or

(3) $\mathrm{EBP}_{\mathrm{t}+1}=\alpha+\beta_{1}$ Post $+\beta_{2} 500 \mathrm{M}_{\mathrm{t}}+\beta_{3}$ Post $^{*} 500 \mathrm{M}_{\mathrm{t}}$

$$
\begin{aligned}
& +\beta_{4} \text { ROA }_{t}+\beta_{5} \text { Post }^{*} \text { ROA }_{t}+\beta_{6} 500 M_{t} * \mathrm{ROA}_{t}+\beta_{7} \text { Post }^{*} 500 \mathrm{M}_{\mathrm{t}} * \mathrm{ROA}_{\mathrm{t}} \\
& +\beta_{8} \text { Size }_{\mathrm{t}}+\beta_{9} \text { Size }_{\mathrm{t}} * \mathrm{ROA}_{\mathrm{t}}+\beta_{10} \text { ADR }+\beta_{11} \text { Post }^{*} \text { ADR } \\
& +\beta_{12} \text { ADR }^{*} \text { ROA }+\beta_{13} \text { ADR }^{*} \text { Post } \text { ROA }_{t}+\mathrm{e}
\end{aligned}
$$

Where:

$\mathrm{ROA}_{\mathrm{t}+\mathrm{n}}-$ Pre-tax Income during year $\mathrm{t}+\mathrm{n}$ scaled by beginning Total Assets;

$\mathrm{EBP}_{\mathrm{t}+1}-$ Pre-tax Income before Loan Loss Provision during year $\mathrm{t}+1$ scaled by beginning Total Assets;

\footnotetext{
${ }^{15}$ Since ROE is also a commonly used performance measure in the banking industry, we also estimated this regression replacing ROA with $\mathrm{ROE}$ and the inferences are unchanged.
} 
Post - $\quad$ An indicator variable that equals one in the post-FDICIA period (after 1992), zero otherwise;

$500 \mathrm{M}_{\mathrm{t}}-$ An indicator variable that equals one if Total Assets $>\$ 500$ million (the FDICIA internal control provision threshold) at both the beginning and end of year t, zero otherwise;

Size $_{t}-\quad$ The Log of Total Assets in millions at the beginning of year t;

ADR - An indicator variable that equals one for non-U.S. banks with ADRs, zero otherwise.

\subsubsection{Earnings Management}

Following Beatty, Ke and Petroni (2002), we investigate whether banks affected by FDICIA were more likely to report small positive earnings changes in the post-period. If, prior to the regulation, managers were using their accounting discretion to manage earnings, then we would expect benchmark beating to decline for affected banks. We estimate the following probit regression on our Regulatory and Compustat samples:

(4) Small_Pos $\Delta_{t}=\alpha+\beta_{1}$ Post $+\beta_{2} 500 \mathrm{M}_{\mathrm{t}}+\beta_{3}$ Post $* 500 \mathrm{M}_{\mathrm{t}}+\beta_{4}$ ADR $+\beta_{5}$ Post $*$ ADR $+\mathrm{B}_{\mathrm{i}}$ Controls $_{\mathrm{t}}+\mathrm{e}$

Where

Small_Pos $\Delta_{t}-$ An indicator variable that equals one if the change in ROA (Pre-tax Income scaled by Total Assets) from year $\mathrm{t}-1$ to year $\mathrm{t}$ is in the interval between 0 and 0.0008 , zero otherwise;

Post - $\quad$ An indicator variable that equals one in the post-FDICIA period (after 1992), zero otherwise;

$500 \mathrm{M}_{\mathrm{t}}-\quad$ An indicator variable that equals one if the firm has Assets $>\$ 500$ million (the FDICIA internal control provision threshold) at both the beginning and end of year $t$, zero otherwise;

ADR - $\quad$ An indicator variable that equals one for non-U.S. banks with ADRs, zero otherwise.

Control variables for our regulatory sample are the ones used in Beatty et al. (2002).

Specifically we include their measures of size, publicly traded status, growth, loans, nonperforming loans, leverage, and change in cash flows. Since information on total loans and non-performing loans is only available for our regulatory sample we substitute the allowance for loan losses for our Compustat Sample. 


\subsubsection{Conservatism}

We also examine whether a change in discretion associated with FDICIA internal controls regulation results in a change in accounting conservatism. Consistent with Ball and Shivakumar (2005), we examine the relationship between a change in earnings and the lagged change in earnings, allowing for differences in positive and negative earnings changes. There are two major advantages of this conservatism measure. First, unlike the Basu (1997) measure, it can be estimated for both our Regulatory and Compustat samples, because it does not require market prices. Second, it provides a somewhat less controversial measure of timely gain and loss recognition. We estimate the following regression on our Regulatory and Compustat samples:

(5) $\Delta \mathrm{ROA}_{\mathrm{t}+1}=\alpha+\beta_{1}$ Post $+\beta_{2} 500 \mathrm{M}_{\mathrm{t}}+\beta_{3}$ Post $^{*} 500 \mathrm{M}_{\mathrm{t}}$ $+\beta_{4} \mathrm{ND}+\beta_{5}$ ND*Post $+\beta_{6} \mathrm{ND} * 500 \mathrm{M}+\beta_{7} \mathrm{ND} *$ Post $* 500 \mathrm{M}$ $+\beta_{8} \Delta$ ROA $_{\mathrm{t}}+\beta_{9}$ Post $^{*} \Delta \mathrm{ROA}_{\mathrm{t}}+\beta_{10} 500 \mathrm{M}_{\mathrm{t}} * \Delta \mathrm{ROA}_{\mathrm{t}}+\beta_{11}$ Post $^{*} 500 \mathrm{M}_{\mathrm{t}} * \Delta \mathrm{ROA}_{\mathrm{t}}$ $+\beta_{12} \mathrm{ND}^{*} \Delta \mathrm{ROA}_{\mathrm{t}}+\beta_{13}$ Post $^{*} \mathrm{ND} * \Delta \mathrm{ROA}_{\mathrm{t}}+\beta_{14} 500 \mathrm{M}_{\mathrm{t}} * \mathrm{ND}^{*} \Delta \mathrm{ROA}_{\mathrm{t}}$ $+\beta_{15}$ Post $^{*} 500 \mathrm{M}_{\mathrm{t}} * \mathrm{ND} * \Delta \mathrm{ROA}_{\mathrm{t}}+\beta_{16}$ Size $_{\mathrm{t}}$ $+\beta_{17}$ ADR $+\beta_{18}$ Post*ADR $+\beta_{19}$ ADR $*$ ND $+\beta_{20}$ Post*ADR*ND $+\beta_{21}$ ADR $^{*} \triangle \mathrm{ROA}+\beta_{22} \mathrm{ADR}^{*}$ Post $^{*} \Delta \mathrm{ROA}_{\mathrm{t}}$ $+\beta_{23}$ ADR $*$ ND* $\Delta$ ROA $+\beta_{24}$ ADR $^{*}$ Post $^{*} \mathrm{ND}^{*} \Delta \mathrm{ROA}_{\mathrm{t}}+\mathrm{e}$

Where:

$\Delta \mathrm{ROA}_{\mathrm{t}+\mathrm{n}}-$ The change in Pre-tax Income during year $\mathrm{t}+\mathrm{n}$ scaled by beginning Total Assets;

Post - An indicator variable that equals one in the post-FDICIA period (after 1992), zero otherwise;

$500 \mathrm{M}_{\mathrm{t}}-$ An indicator variable that equals one if Total Assets $>\$ 500$ million (the FDICIA internal control provision threshold) at both the beginning and end of year $t$, zero otherwise;

$\mathrm{ND} \quad-$ An indicator variable that equals one if $\triangle \mathrm{ROA}_{\mathrm{t}}$ is negative, zero otherwise;

Size $_{t} \quad-$ The Log of Total Assets in millions at the beginning of year $t$;

ADR - An indicator variable that equals one for non-U.S. banks with ADRs, zero otherwise. 


\subsection{Quarterly Analysis}

Given the FDICIA requirement that banks assess their internal controls environment regularly throughout the year, we expect this regulation to have a greater impact during interim reporting periods, which are subject to less auditor scrutiny. For our Regulatory sample, we re-run each of our primary annual regressions using quarterly data allowing the coefficients to differ for the interim quarters versus the fourth quarter.

\subsection{Direct Costs of Internal Control Regulation}

Internal controls regulation results in both direct and indirect costs. Direct costs arise from increased audit fees and compensation for Boards of Directors, including Audit Committees. Indirect costs arise if managers ignore important activities instead of focusing on fine-tuning internal controls or if they spend more time reviewing major decisions, evaluating and re-evaluating financial reports, and compiling information for their boards of directors. Measuring these indirect costs is especially difficult. However, we are able to examine how the non-interest expense of banks affected by the FDICIA internal controls provisions changed after the implementation of this regulation.

Figure 2 provides the yearly amount of other non-interest expense, scaled by total assets, for banks that were affected versus unaffected by FDICA's internal control provision. Other non-interest expense includes audit fees and other fees paid to outsiders, including directors and consultants. The chart suggests that the non-operating expense ratio was lower for the affected banks than for the unaffected banks prior to the passage of FDICIA. The expense ratio increased for affected banks in the post-FDICIA period, although the extent to which the ratio for affected banks exceeds that for unaffected 
banks has decreased over time. The increase in this expense ratio for the affected banks, while not conclusive, is descriptively interesting.

\subsection{Sensitivity Tests}

Although market conditions during our sample period were relatively stable, important changes occurred in the banking industry during this period, including (1) a merger wave associated with the Riegle-Neal Act that opened up nationwide branching and (2) the repeal of Glass-Steagal restrictions on investment banking activity as a result of the passage of the 1999 Gramm-Leach-Bliley Act. Although we use two different control samples to reduce the likelihood that these sorts of changes affect our results, we perform sensitivity tests that identify banks likely affected by these changes.

\section{Results}

\subsection{Descriptive Statistics}

Table 1 provides descriptive statistics about the affected versus unaffected banks in each of our two samples in the pre- and post-FDICIA periods. On average, the sample banks report positive pre-tax earnings and positive earnings before the loan loss provision, our proxy for cash flows from operations. The average size of the banks in our Compustat sample is larger than in our Regulatory sample.

\subsection{Annual Regressions}

In Table 2, we provide the results of our loan-loss models. The primary coefficient of interest is on the loan loss provision in the post-period for affected banks $\left(\right.$ Post $\left.* 500 \mathrm{M}_{\mathrm{t}} * \operatorname{LLP}_{t}\right)$. For both samples, we find a significantly positive relationship, at the $1 \%$ level, between this variable and one-period ahead loan charge-offs $\left(\mathrm{CHGOFF}_{t+1}\right)$. This finding indicates a stronger association between accrual and operating activity for 
affected relative to unaffected banks during the post-period. ${ }^{17}$ We also find a significantly negative coefficient on the interaction of ADR and $\mathrm{LLP}_{t}$ in the post-period, consistent with the ADR firms being unaffected by FDICIA's internal control provisions.

The lack of significant coefficients on $500 \mathrm{M}_{t} * \mathrm{LLP}_{\mathrm{t}}$ and $\mathrm{ADR} * \mathrm{LLP}_{\mathrm{t}}$ provides no evidence that the association between the provision and charge-offs of our affected and unaffected banks differ in the pre-regulation period for either of our control samples. The insignificance of these variables given the significance for our variables of interest suggests that a lack of power is not driving our failure to find a difference. These findings support the appropriateness of these two control samples.

Table 3 provides the results of our earnings persistence and predictability of future cash flows models. We find significantly positive coefficients on Post $* 500 \mathrm{M}_{\mathrm{t}} * \mathrm{ROA}_{\mathrm{t}}$ in both models. These findings are consistent with greater earnings persistence and greater earnings predictability of future cash flows for affected banks relative to unaffected banks in the post-period. The latter finding suggests that the improvements in earnings quality are not solely the result of provision smoothing. The coefficient on Post*ADR*ROA is significantly negative in both models, indicating that this improvement is mitigated for the ADR banks unaffected by the regulation.

The lack of significant coefficients in the persistence regressions on the $500 \mathrm{M}_{\mathrm{t}} * \mathrm{ROA}_{\mathrm{t}}$ variable for both the Regulatory and COMPUSTAT samples combined with the lack of significance on the $\mathrm{ADR} * \mathrm{ROA}_{t}$ coefficient in the predictability model provides some additional assurance that our control samples are appropriate, since we

\footnotetext{
${ }^{17}$ Since loans may be charged-off in the same period they are provided for, we do not expect a one-to-one relationship between the current provision and next periods' charge-offs. As a sensitivity test, we reestimate the charge-off model using the sum of current and next period's charge-offs as the dependent variable. The significance of the results increases using this specification.
} 
detect no difference in reporting characteristics between the test and control firms in the pre-period. ${ }^{18}$ Overall, the results for both samples are consistent with the FDICIA internal control requirements leading to improvements in earnings persistence and predictability of future cash flows for banks affected by the regulation.

We present the results of our benchmark-beating analysis in Table 4 . We find a significantly negative relationship, at the $1 \%$ level, between our primary variable of interest, Post $* 500 \mathrm{M}_{\mathrm{t}}$ and the reporting of small positive earnings changes. ${ }^{19}$ This finding is consistent with affected banks being less likely to engage in benchmark beating than unaffected banks in the post-period. We also find that the coefficient for ADR banks in the post-period is positive and significant at the $5 \%$ level. The results for both samples indicate that the internal controls regulation resulted in less benchmark beating.

Table 5 reports the accounting conservatism regression results. In both samples, we find a significantly positive coefficient on the primary variable of interest, Post $* 500 \mathrm{M}_{\mathrm{t}} * \mathrm{ND}^{*} \Delta \mathrm{ROA}_{\mathrm{t}}$, indicating that the timeliness of loss recognition declined for affected firms in the post-regulatory period. This finding suggests a relative decline in reporting conservatism associated with the internal controls regulation. We also find that the coefficient on the ADR*Post*ND* $\Delta \mathrm{ROA}_{\mathrm{t}}$ variable is negative, indicating that the decline in conservatism is mitigated for these banks unaffected by the regulation. ${ }^{20}$

Reduced conservatism in affected banks could result from a reduction in the large supplemental reserves that concerned the GAO (1994). Based on Bagnoli and Watts'

\footnotetext{
${ }^{18}$ For the COMPUSTAT sample, we do find a significant coefficient on the $500 \mathrm{M} * \mathrm{ROA}_{\mathrm{t}}$ variable in the predictability model and on the $\mathrm{ADR} * \mathrm{ROA}_{\mathrm{t}}$ variable in the persistence model.

${ }^{19}$ Consistent with Beatty et al. (2002), we include a variable measuring the change in cash flows in our benchmark beating analysis. Since our cash flow measure is highly correlated with our earnings measure, we omit the change in cash flows in a sensitivity test and obtain results consistent with those tabulated. ${ }^{20}$ As an additional sensitivity check, we also estimated the Basu (1997) measure for our COMPUSTAT sample and found similar results.
} 
(2005) argument, this reduction in discretion may inhibit managers' ability to convey private information, thereby reducing the overall information quality of their reports.

\subsection{Quarterly Regressions}

In Table 6 we report the results of our loan-loss models estimated using quarterly data. The two variables of interest are Post $* 500 \mathrm{M}_{\mathrm{t}} * \operatorname{LLP}_{\mathrm{q}}$, which measures the affect of the regulation in the fourth quarter and Post $* 500 \mathrm{M}_{\mathrm{t}} * \mathrm{Q} * \mathrm{LLP}_{\mathrm{q}}$, which measures the incremental affect of the regulation in the interim quarters relative to the fourth quarter. The positive and marginally significant coefficient on Post $* 500 \mathrm{M}_{\mathrm{t}} * \mathrm{LLP}_{\mathrm{q}}$ indicates a slight improvement in the association between the loan loss provision and charge-offs in the fourth quarter for affected relative to unaffected banks. The positive and significant coefficient on Post $* 500 \mathrm{M}^{*} \mathrm{Q} * \mathrm{LLP}_{\mathrm{q}}$, indicates that this effect is greater in the first three quarters than in the fourth quarter. This finding is consistent with an increased auditor presence in the fourth quarter substituting for internal control regulation.

We find no evidence of a difference in the relation between the provision and charge-offs between our affected versus unaffected banks in the pre-regulation period based on the insignificant coefficients on the $500 \mathrm{M}_{\mathrm{q}} * \mathrm{LLP}$ and the $500 \mathrm{M}_{\mathrm{q}} * \mathrm{Q}^{*} \mathrm{LLP}_{\mathrm{q}}$ variables. Again, this finding supports the appropriateness of our control sample.

Table 7 provides the results of our quarterly analysis of earnings persistence and predictability of future cash flows. The results provide no evidence of a relative improvement in earnings quality in the fourth quarter for affected versus unaffected banks given the lack of significance on the Post $* 500 \mathrm{M}_{\mathrm{q}} * \mathrm{ROA}$ variable. However, the positive and significant coefficients on the Post $* 500 \mathrm{M}_{\mathrm{q}} * \mathrm{Q} * \mathrm{ROA}$ variable in both models suggests that the regulation improved the quality of reported earnings in the first through 
third quarters for affected banks relative to those unaffected by the internal controls regulation. The lack of significant coefficients on the $500 \mathrm{M}_{\mathrm{q}} * \mathrm{ROA}_{\mathrm{q}}$ and $500 \mathrm{M}_{\mathrm{q}} * \mathrm{Q} * \mathrm{ROA}_{\mathrm{q}}$ variables, coupled with our findings in the post-FDICIA period, again supports the appropriateness of our control sample.

We also conduct quarterly benchmark beating and accounting conservatism regressions. Although we document a reduction in the frequency of benchmark beating and a decrease in conservatism for our affected firms in the post- FDICIA period we find no evidence of a difference between interim and four quarters in either analysis.

Taken together, these results suggest that an increased auditor presence might partially substitute for the effects of internal control regulation given the larger effect found in the interim quarters for the validity of the loan loss provision and the quality of reported earnings. The lack of a difference between the interim and fourth quarters for the benchmark beating and conservatism measures may reflect a lack of power or suggest that auditors focused less on these elements of financial reporting, allowing the internal controls regulation to have a more pervasive impact.

\section{Sensitivity Analyses}

Although we use two distinct control groups to alleviate concerns about a bias arising from differences between our test and control firms, we perform several sensitivity tests to provide further evidence that our control samples effectively isolate the effects of FDICIA internal control provisions. We do not tabulate any of these results.

\subsection{Size Stratification and Public Versus Private Firms}

We conduct four sensitivity analyses to address concerns about size differences between our test and control samples. First, we include a non-linear measure of size (the 
square of total assets) in addition to the log measure, with no change in our results.

Second, we define two indicator variables, Small, if total assets are less $\$ 250$ million, and Big, if total assets exceed $\$ 60$ billion. ${ }^{21}$ Whether we estimate the regressions separately for each indicator or combining both indicators, our results are unchanged when we allow the primary coefficients of interest in our annual regressions to differ for Small and for Big banks. This indicates that our results are not driven by either the smallest or largest firms in our sample, since our results hold when we compare banks with assets greater than $\$ 500$ million but less than $\$ 60$ billion to those with assets between $\$ 250$ - $\$ 500$ million. Third, we replace our Big variable with an indicator variable that equals one if affected banks have assets greater than $\$ 1$ billion, zero otherwise. Again we find that our results do not appear to be driven by banks of a particular size, since our results hold when we compare banks with assets greater than $\$ 500$ million but less than $\$ 1$ billion to either those with assets less than $\$ 500$ million or to those with assets between $\$ 250-\$ 500$ million. Finally, we separately examine only affected firms broken into size deciles. We find no systematic evidence of a difference in the estimated coefficients based on these size deciles.

We also examine whether our results differ for publicly traded versus privately held banks. We re-run our primary analyses allowing the coefficients to differ for SEC filers versus non-filers. The results are very similar across all tests other than the benchmark beating where the results become insignificant for the non-filers. Overall, the split between public and private firms does not alter our inferences.

\footnotetext{
${ }^{21} \$ 250$ million is the median asset size for the regulatory sample. \$60 billion in assets is the average for the sample examined in Liu and Ryan (2006) and these banks represent the top one percent of our sample and hold half of the total assets held by the banks in our sample.
} 


\subsection{Growth and Mergers}

We also examine the sensitivity of our results to growth by estimating our models separately for Regulatory sample banks with asset growth above the 7\% median growth rate, versus those with asset growth below the median. Our results are unchanged providing no evidence that the bank merger wave during this period drives our results. To further assess this possibility, we constructed a merger indicator variable for banks with asset growth above $13 \%$, the $75^{\text {th }}$ percentile growth rate. This growth rate exceeds the $10 \%$ organic growth rate that A.T. Kearny (2005) argues is an "aggressive, if not unrealistic" organic growth rate. We again find no differences in the coefficients for high versus low growth for affected versus unaffected banks, in either the pre- or postregulatory period, providing no evidence that asset growth drives our results.

Since mergers and acquisitions affect entry and exit, we also compare these rates for the affected versus unaffected samples. We find no difference in exit rates, but we find that $18 \%$ of affected firms versus $26 \%$ of unaffected firms enter our sample in the pre-period. We also note that in the post-period, $40 \%$ of affected and $76 \%$ of unaffected firms enter our sample. This difference in entrance rates could potentially bias towards our results if the entering unaffected firms have weaker financial reporting quality measures. However, we re-estimate our models for firms entering the sample after 1987 versus those originally in the sample, and find no significant difference between the two groups, suggesting that differences in survivorship do not drive our results.

\subsection{Macro-Economic Controls}

To control for changes in economic conditions we also re-estimated our models including control variables for both changes in the seven versus one year Treasury bill 
rates and changes in credit spreads on BAA versus AAA rated debt. Our results are unaffected by controlling for these changes in interest rates and credit spreads.

\subsection{Debt-dominated Economies}

To ensure that the ADR results are not driven by differences in banks located in debt-dominated economies, we allowed the coefficients on our ADR variables to differ for banks from Common Law versus Code Law countries using La Porta et al.'s (2000) classification. La Porta et al. (2000) report that on average, equity finances $60 \%$ of GNP for English Common Law countries while it averages only 32\% for civil law countries. We find no significant difference in the estimated coefficients on any of our ADR variables between Common Law and Code Law countries suggesting that this distinction is not driving our results.

\section{Conclusion}

We examine the internal control provisions mandated by FDICIA during the early 1990s to investigate how internal control regulation affects financial reporting. Our study examines both the validity of specific accounts and the quality of financial reporting. We identify two sets of control firms unaffected by the FDICIA internal control regulations, and use a difference-in-differences research design to examine changes in the loan-loss provision validity, earnings persistence, earnings predictability, benchmark beating behavior, and accounting conservatism. We validate our control samples by testing for differences between the affected and unaffected firms in the period prior to the regulation. This research design has many advantages, including the ability to control for macro-economic effects and other regulatory changes, allowing us to isolate the impact of FDICIA internal control provisions on the examined financial reporting characteristics. 
Our results are consistent with FDICIA internal control requirements leading to a greater association between the loan loss provision and loan charge-offs. Based on the SAB 102 criteria, this suggests an improvement in the validity of the loan loss provision We also document improvements in earnings' persistence and predictability of cash flows and find evidence of reduced earnings management activity, in the form of benchmarkbeating, in the post-FDICA period. Taken together, these results suggest that improvements in internal control monitoring and reporting lead to improvements in the quality of financial reporting in the banking industry. However, we also document a decrease in accounting conservatism resulting from the internal control regulation. For some, this may support the interpretation of improved reporting quality. However, others may view a reduction in conservatism negatively.

By examining the FDICIA internal control provisions, we study the first regulatory adoption of the COSO framework. Given COSO's pivotal role in more recent internal control regulations, including SOX, we argue that our results are important in understanding the evolution of internal control regulation. The current financial crisis has once again called into question the need for internal control regulation with some arguing for increased regulation, while others argue that the failure of existing regulation to prevent this crisis suggests that additional regulation would be futile. Existing internal control regulation research, particularly examining SOX, has had difficulty disentangling the effects of the regulation from other contemporaneous events because of the lack of a control sample of firms unaffected by the legislation. Our setting and our difference-indifferences research design allow us to make inferences about potential market-wide implications of changes in internal control regulations. In addition, by examining the 
average financial reporting impact for all institutions affected by the FDICIA internal control provisions, our results help assess whether the regulation improved financial reporting for the industry as a whole. Therefore, we believe the results of this study should provide valuable information to regulators and practitioners who are currently debating the ever-changing landscape of internal controls regulation. 


\section{References}

Ashbaugh-Skaife, H., Collins, D., Kinney, W., 2007. The discovery and consequences of internal control deficiencies prior to SOX-mandated audits. Journal of Accounting and Economics 44, 166-192.

Ashbaugh-Skaife, H., Collins, D., LaFond, R., Kinney W., 2008. The effect of internal control deficiencies and their remediation on accrual quality. The Accounting Review 83 (1), 217-250.

A.T. Kearney. 2005. Rising to the growth challenge. A.T. Kearney Publications.

Bagnoli, M., and Watts, S., 2005. Financial reporting and supplemental voluntary disclosures. Journal of Accounting Research 45 (5), 885-913.

Ball, R., Shivakumar, L., 2005. Earnings quality in U.K. private firms: comparative loss recognition timeliness. Journal of Accounting \& Economics 39, 83-128.

Basu, S., 1997. The conservatism principle and asymmetric timeliness of earnings. Journal of Accounting \& Economics 24, 3-37.

Beatty, A., Ke, B., Petroni, K., 2002. Earnings management to avoid earnings declines across publicly and privately held banks. The Accounting Review 77, 547-570.

Benston, G. and G. Kaufman. 1998. Deposit insurance reform in the FDIC improvement act: the experience to date. Economic Perspectives 2, 2-20.

Boyd, J. ,L. Daley, and D. Runkle. 1994. The seasonality of interim discretionary accruals: The case of loan- loss provisions and charge-offs in the banking industry. Working Paper.

Carnell, S., 1997. Treasury defends FDICIA bank reform. Journal of Accountancy 183, 15.

Coates IV, J. C., 2007. The Goals and Promise of the Sarbanes-Oxley Act. Journal of Economic Perspectives 21 (1), 91-116.

Cohen, D., Dey, A., Lys, T., 2008. Real and accrual-based earnings management in the pre- and post-sarbanes oxley periods. The Accounting Review 77, 757-787.

Compliance Week ICD database. http://www.complianceweek.com/search/controlsprocedures.

Cox, C., 2007. Testimony concerning reporting on the internal controls of small businesses under section 404 of the sarbanes-oxley act of 2002. Washington D.C. www.sec.gov 
Dechow, P. and Dichev, I., 2002. The quality of accruals and earnings: The role of accrual estimation errors. The Accounting Review 77 (Supplement), 35-59.

Doyle, J., Ge, W., McVay, S., 2007. Determinants of weaknesses in internal control over financial reporting and the implications for earnings quality. Journal of Accounting and Economics 44, 193-223.

Francis, J., LaFond, R., Olsson, P., Schipper, K., 2004. Costs of equity and earnings attributes. The Accounting Review 79, 967-1010.

GAO, 1991. Failed Banks: Accounting and auditing reforms urgently needed. United States General Accounting Office - Report to Congressional Committees.

GAO, 1994. Depository institutions: divergent loan loss methods undermine usefulness of financial reports. United States General Accounting Office - Report to Congressional Committees.

GAO, 1996. Bank and thrift regulation: implementation of FDICIA's prompt regulatory action provisions. United States General Accounting Office - Report to Congressional Committees.

Hochberg, Y., Vissing-Jorgensen, A., Sapienza, P., 2009. A lobbying approach to evaluating the Sarbanes-Oxley act of 2002. Journal of Accounting Research 47 (2), 519583.

Kanagaretnam, K., Lobo, G., Yang D., 2004. Joint tests of signaling and income smoothing through bank loan loss provisions. Contemporary Accounting Research 21, 843-884.

La Porta, R., Lopez de Silanes, F., Shleifer, A., Vishny, R., 2000. Investor protection and corporate governance. Journal of Financial Economics 58, 3-27.

Leuz, C., Nanda, D., and Wysocki, P., 2003. Earnings Management and Investor Protection: An International Comparison. Journal of Financial Economics 69, 505-527.

Liu, C.C., Ryan, S., 2006. Income smoothing over the business cycle: Changes in banks coordinated management of provisions for loan losses and loan charge-offs from the pre1990 bust to the 1990s boom. The Accounting Review 81, 413-443.

Mendenhall, R., Nichols, W., 1988. Bad news and differential market reactions to announcements of earlier versus fourth quarter earnings. Journal of Accounting Research (Supplement), 63-86.

Mishkin, F.S., "Evaluating FDICIA” in George G. Kaufman, ed., FDICIA: Bank reform five years later and five years ahead, Greenwich, CT.: JAI Press, 1997, pp. 17-33. 
Murphy, C.W., 2004. Goodbye FDICIA, hello Sarbox - sort of. PricewaterhouseCoopers Publications.

Niemeier, C. 2006. Remarks before the national association of state boards of accountancy. Atlanta, GA. www.pcaobus.org

Ogneva, M., Subramanyam, K.R., Raghunandan, K.. 2007. Internal control weakness and cost of equity: evidence from Sox section 404 disclosures. The Accounting Review $82,1255-1297$.

Petersen, M., 2009. Estimating standard errors in finance panel data sets:

Comparing approaches. Review of Financial Studies, Review of Financial Studies 22, 435-480.

Smith F. L., 2003. Cowboys versus cattle thieves: the role of innovative institutions in managing risks along the frontier, in Christopher L. Culp and William A. Niskanen, editors, Corporate Aftershock: The Public Policy Lessons From the Collapse of Enron and Other Major Corporations, John Wiley \& Sons: Hoboken, New Jersey.

Standard \& Poor's. 2002. Accounting for impaired assets in credit analysis. McGraw Hill.

Turley, J., 2008. The changing dynamics of global capital markets. United States Chamber of Commerce - Global Capital Markets Summit, www.uschamber.com/press/speeches/2008/080326_turley.htm

Watts, R., 3003. Conservatism in accounting part I, explanations and implications. Accounting Horizons 17, 207-221.

Wahlen, J.M., 1994. The nature of information in commercial bank loan loss disclosures. The Accounting Review 69 (3), 455-78.

Wysocki, P., 2005. Assessing earnings quality: U.S. and international evidence. Working paper, Massachusetts Institute of Technology.

Zhang, I., 2007. Economic consequences of the Sarbanes-Oxley act of 2002. Journal of Accounting and Economics, 44, 75-122. 


\section{Table 1}

Mean and (standard deviation) of characteristics

Panel A: Regulatory Sample

\begin{tabular}{|c|c|c|c|c|}
\hline & \multicolumn{2}{|c|}{ Pre-Regulation Period } & \multicolumn{2}{|c|}{ Post Regulation Period } \\
\hline Variable & $<500 \mathrm{M}^{*}$ & $>500 \mathrm{M}^{* *}$ & $<500 \mathrm{M}^{*}$ & $>500 \mathrm{M}^{* *}$ \\
\hline $\mathrm{CHGOFF}_{\mathrm{t}+1}$ & $\begin{array}{c}0.0050 \\
(0.0057)\end{array}$ & $\begin{array}{c}0.0078 \\
(0.0066)\end{array}$ & $\begin{array}{c}0.0022 \\
(0.0031)\end{array}$ & $\begin{array}{c}0.0031 \\
(0.0038)\end{array}$ \\
\hline $\mathrm{LLP}_{\mathrm{t}}$ & $\begin{array}{c}0.0046 \\
(0.0049)\end{array}$ & $\begin{array}{c}0.0066 \\
(0.0059)\end{array}$ & $\begin{array}{c}0.0020 \\
(0.0025)\end{array}$ & $\begin{array}{c}0.0025 \\
(0.0030)\end{array}$ \\
\hline $\mathrm{ROA}_{\mathrm{t}+1}$ & $\begin{array}{l}0.0093 \\
(0.0092)\end{array}$ & $\begin{array}{l}0.0083 \\
(0.0090)\end{array}$ & $\begin{array}{c}0.0152 \\
(0.0066)\end{array}$ & $\begin{array}{c}0.0170 \\
(0.0064)\end{array}$ \\
\hline $\mathrm{EBP}_{\mathrm{t}+1}$ & $\begin{array}{c}0.0138 \\
(0.0067)\end{array}$ & $\begin{array}{c}0.0150 \\
(0.0063)\end{array}$ & $\begin{array}{c}0.0175 \\
(0.0060)\end{array}$ & $\begin{array}{c}0.0196 \\
(0.0065)\end{array}$ \\
\hline Small_Pos $\Delta_{t}$ & $\begin{array}{c}0.1164 \\
(0.3207)\end{array}$ & $\begin{array}{c}0.1670 \\
(0.3730)\end{array}$ & $\begin{array}{c}0.1138 \\
(0.3177)\end{array}$ & $\begin{array}{c}0.1351 \\
(0.3418)\end{array}$ \\
\hline$\overline{\text { Size }_{\mathrm{t}}}$ & $\begin{array}{c}5.0230 \\
(0.6682)\end{array}$ & $\begin{array}{c}7.8710 \\
(1.2581)\end{array}$ & $\begin{array}{c}5.4600 \\
(0.3283)\end{array}$ & $\begin{array}{c}7.8461 \\
(1.3446)\end{array}$ \\
\hline
\end{tabular}

Panel B: COMPUSTAT Sample

\begin{tabular}{|l|c|c|c|c|c|c|}
\hline & \multicolumn{3}{|c|}{ Pre-Regulation Period } & \multicolumn{3}{c|}{ Post Regulation Period } \\
\hline Variable & $<500 \mathrm{M}^{*}$ & $>500 \mathrm{M}^{* *}$ & ADR*** & $<500 \mathrm{M}^{*}$ & $>500 \mathrm{M}^{* *}$ & ADR*** \\
\hline CHGOFF $_{\mathrm{t}+1}$ & 0.0053 & 0.0058 & 0.0052 & 0.0018 & 0.0023 & 0.0043 \\
& $(0.0065)$ & $(0.0054)$ & $(0.0037)$ & $(0.0033)$ & $(0.0027)$ & $(0.0047)$ \\
\hline LLP $_{\mathrm{t}}$ & 0.0051 & 0.0066 & 0.0073 & 0.0028 & 0.0036 & 0.0070 \\
& $(0.0048)$ & $(0.0062)$ & $(0.0036)$ & $(0.0041)$ & $(0.0030)$ & $(0.0072)$ \\
\hline ROA $_{\mathrm{t}+1}$ & 0.0057 & 0.0081 & 0.0092 & 0.0128 & 0.0168 & 0.0100 \\
& $(0.0015)$ & $(0.0098)$ & $(0.0073)$ & $(0.0091)$ & $(0.0063)$ & $(0.0088)$ \\
\hline EBP $_{\mathrm{t}+1}$ & 0.0123 & 0.0154 & 0.0177 & 0.0154 & 0.0196 & 0.0174 \\
& $(0.0125)$ & $(0.0057)$ & $(0.0053)$ & $(0.0078)$ & $(0.0061)$ & $(0.0096)$ \\
\hline Small_Pos $_{\mathrm{t}}$ & 0.0938 & 0.1922 & 0.1538 & 0.1504 & 0.1999 & 0.1788 \\
& $(0.2938)$ & $(0.3942)$ & $(0.3655)$ & $(0.3576)$ & $(0.4000)$ & $(0.3842)$ \\
\hline Size $_{\mathrm{t}}$ & 5.4903 & 8.7112 & 11.3674 & 5.4440 & 7.9380 & 10.7346 \\
& $(0.4930)$ & $(1.1800)$ & $(0.8282)$ & $(0.4758)$ & $(1.4812)$ & $(1.5504)$ \\
\hline
\end{tabular}

* Total Assets $<\$ 500$ million (FDICIA internal control provision threshold)

** Total Assets $>\$ 500$ million (FDICIA internal control provision threshold)

***International bank with ADRs

Variable Definitions:

$\mathrm{CHGOFF}_{\mathrm{t}+1} \quad$ - Loan charge-offs during year $\mathrm{t}+1$, scaled by beginning Total Assets;

$\mathrm{LLP}_{\mathrm{t}} \quad-$ Loan-loss provision during year $\mathrm{t}$, scaled by beginning Total Assets;

ROA $_{t+n} \quad$ - Pre-tax Income during year $\mathrm{t}+\mathrm{n}$ scaled by beginning Total Assets;

$\mathrm{EBP}_{\mathrm{t}+1} \quad-$ Pre-tax Income before Loan Loss Provision during year $\mathrm{t}+1$ scaled by Beginning Total Assets;

Small_Pos $\Delta_{\mathrm{t}} \quad-$ An indicator variable that equals one if the change in ROA (Pre-tax Income scaled by Total Assets) from year $\mathrm{t}-1$ to year $\mathrm{t}$ is in the interval between 0 and 0.0008 , zero otherwise;

Size $_{\mathrm{t}} \quad-$ The natural log of Total Assets in millions at the beginning of year $\mathrm{t}$; 
Table 2

Coefficients (clustered t-statistics) from annual cross-sectional charge-off regressions for Regulatory and COMPUSTAT samples.

\begin{tabular}{|c|c|c|c|c|c|}
\hline \multirow[b]{3}{*}{ Variable } & \multirow[b]{3}{*}{$\begin{array}{l}\text { Predicted } \\
\text { Sign }\end{array}$} & \multicolumn{4}{|c|}{$\mathrm{CHGOFF}_{\mathrm{t}+1}$} \\
\hline & & \multicolumn{2}{|c|}{ Regulatory } & \multicolumn{2}{|c|}{ COMPUSTAT } \\
\hline & & Coefficient & (t-statistic) & Coefficient & (t-statistic) \\
\hline Intercept & $+/-$ & -0.0032 & $(-4.86)^{* * *}$ & -0.0016 & $(-2.21)^{* *}$ \\
\hline Post & $+/-$ & -0.0008 & $(-7.20)^{* * *}$ & -0.0003 & $(-0.48)$ \\
\hline $500 \mathrm{M}_{\mathrm{t}}$ & $+/-$ & -0.0003 & $(-1.69)^{*}$ & -0.0002 & $(-0.24)$ \\
\hline Post* $500 \mathrm{M}_{\mathrm{t}}$ & $+/-$ & -0.0006 & $(-2.56)^{* *}$ & -0.0006 & $(-1.01)$ \\
\hline $\mathrm{LLP}_{\mathrm{t}}$ & + & 0.7513 & $(4.98) * * *$ & 1.0021 & $(7.99)^{* * *}$ \\
\hline Post*LLP $_{t}$ & $+/-$ & 0.0600 & $(1.16)$ & -0.3377 & $(-4.29) * * *$ \\
\hline $500 \mathrm{M}_{\mathrm{t}} * \mathrm{LLP}_{\mathrm{t}}$ & $+/-$ & 0.0003 & $(0.01)$ & -0.1199 & $(-1.29)$ \\
\hline Post $^{*} 500 \mathrm{M}_{\mathrm{t}} * \mathrm{LLP}_{\mathrm{t}}$ & + & 0.2883 & $(3.32) * * *$ & 0.3498 & $(3.36)^{* * *}$ \\
\hline Size $_{\mathrm{t}}$ & $+/-$ & 0.0003 & $(6.21)^{* * *}$ & 0.0004 & $(5.84)^{* * *}$ \\
\hline Size $_{t}^{*}$ LLP $_{t}$ & $+/-$ & -0.9890 & $(-0.98)$ & -0.0291 & $(-1.63)$ \\
\hline Nonacc $_{t}$ & + & 0.1500 & $(17.37)^{* * *}$ & $\mathrm{~N} / \mathrm{A}$ & $\mathrm{N} / \mathrm{A}$ \\
\hline ADR & $+/-$ & & & -0.0026 & $(-3.93)^{* *}$ \\
\hline Post*ADR & $+/-$ & & & 0.0026 & $(2.65)^{* *}$ \\
\hline $\mathrm{ADR}^{*} \mathrm{LLP}_{\mathrm{t}}$ & $+/-$ & & & 0.1182 & $(1.39)$ \\
\hline ADR $^{*}$ Post $^{*} \mathrm{LLP}_{\mathrm{t}}$ & - & & & -0.3139 & $(-1.89)^{* *}$ \\
\hline $\begin{array}{l}\text { Number of Observations } \\
\text { Adj R-squared }\end{array}$ & & $\begin{array}{l}16,191 \\
0.5628\end{array}$ & & $\begin{array}{l}4,401 \\
0.5727\end{array}$ & \\
\hline
\end{tabular}

$*, * *, * * *$ significant at the $10 \%, 5 \%$ and $1 \%$ levels, respectively, based on a one- or two-tailed test, as appropriate.

Variable Definitions:

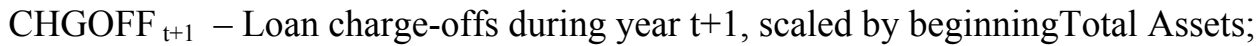

$\mathrm{LLP}_{\mathrm{t}} \quad$ - Loan-loss provision during year $\mathrm{t}$, scaled by beginningTotal Assets;

Post $\quad-$ An indicator variable that equals one in the post-FDICIA period (after 1992), zero otherwise;

$500 \mathrm{M}_{\mathrm{t}}-$ An indicator variable that equals one if Total Assets $>\$ 500$ million (the FDICIA internal control provision threshold) at both the beginning and end of year $t$, zero otherwise;

Size $_{\mathrm{t}} \quad-$ The Log of Total Assets in millions at the beginning of year $\mathrm{t}$;

Nonacc $_{\mathrm{t}} \quad$ - Non-performing at then end of year $\mathrm{t}$, scaled by beginning Total Assets;

ADR $\quad-$ An indicator variable that equals one for non-U.S. banks with ADRs, zero otherwise 
Table 3

Coefficients (clustered t-statistics) from annual cross-sectional earnings persistence and predictability of cash flows regressions for Regulatory and COMPUSTAT samples

\begin{tabular}{|c|c|c|c|c|c|}
\hline & & \multicolumn{2}{|c|}{$\mathrm{ROA}_{\mathrm{t}+1}$} & \multicolumn{2}{|c|}{$\mathrm{EBP}_{\mathrm{t}+1}$} \\
\hline & & Regulatory & COMPUSTAT & Regulatory & COMPUSTAT \\
\hline Variable & Sign & $\begin{array}{l}\text { Coefficient } \\
\text { (t-statistic) }\end{array}$ & $\begin{array}{l}\text { Coefficient } \\
\text { (t-statistic) }\end{array}$ & $\begin{array}{l}\text { Coefficient } \\
\text { (t-statistic) }\end{array}$ & $\begin{array}{l}\text { Coefficient } \\
\text { (t-statistic) }\end{array}$ \\
\hline Intercept & $+/-$ & $\begin{array}{l}-0.0014 \\
(-0.92)\end{array}$ & $\begin{array}{l}-0.0009 \\
(-0.52)\end{array}$ & $\begin{array}{l}-0.0018 \\
(-1.30)\end{array}$ & $\begin{array}{l}0.0070 \\
(3.83)^{* * *}\end{array}$ \\
\hline Post & $+/-$ & $\begin{array}{l}0.0009 \\
(2.87)^{* * *}\end{array}$ & $\begin{array}{l}0.0043 \\
(2.73)^{* * *}\end{array}$ & $\begin{array}{l}-0.0026 \\
(-8.25)^{* * *}\end{array}$ & $\begin{array}{l}0.0001 \\
(0.11)\end{array}$ \\
\hline $500 \mathrm{M}_{\mathrm{t}}$ & $+/-$ & $\begin{array}{l}-0.0007 \\
(-1.41)\end{array}$ & $\begin{array}{l}0.0013 \\
(0.67)\end{array}$ & $\begin{array}{l}-0.0005 \\
(-1.11)\end{array}$ & $\begin{array}{c}0.0024 \\
(1.94)^{* *}\end{array}$ \\
\hline Post*500M & $+/-$ & $\begin{array}{l}0.0007 \\
(1.33)\end{array}$ & $\begin{array}{l}-0.0016 \\
(-0.89)\end{array}$ & $\begin{array}{l}-0.0013 \\
(-2.12)^{* *}\end{array}$ & $\begin{array}{l}-0.0029 \\
(-2.28)^{* *}\end{array}$ \\
\hline $\mathrm{ROA}_{t}$ & + & $\begin{array}{l}0.9522 \\
(8.66)^{* * *}\end{array}$ & $\begin{array}{l}0.9220 \\
(8.34)^{* * *}\end{array}$ & $\begin{array}{l}0.7167 \\
(7.48)^{* * *}\end{array}$ & $\begin{array}{l}0.6010 \\
(5.52)^{* * *}\end{array}$ \\
\hline Post*ROA $_{t}$ & $+/-$ & $\begin{array}{l}-0.0054 \\
(-0.26) \\
\end{array}$ & $\begin{array}{l}-0.1887 \\
(-2.11)^{* *}\end{array}$ & \begin{tabular}{|l|}
0.1539 \\
$(7.22)^{* * *}$ \\
\end{tabular} & \begin{tabular}{|l|}
-0.0656 \\
$(-1.04)$ \\
\end{tabular} \\
\hline $500 \mathrm{M}_{\mathrm{t}} * \mathrm{ROA}_{\mathrm{t}}$ & $+/-$ & $\begin{array}{l}-0.0523 \\
(-1.49) \\
\end{array}$ & $\begin{array}{l}-0.1692 \\
(-1.42) \\
\end{array}$ & $\begin{array}{l}-0.0414 \\
(-1.37) \\
\end{array}$ & $\begin{array}{l}-0.2609 \\
(-2.96)^{* * *}\end{array}$ \\
\hline Post $^{*} 500 \mathrm{M}_{\mathrm{t}} * \mathrm{ROA}_{\mathrm{t}}$ & $+/-$ & $\begin{array}{l}0.0724 \\
(1.96) * *\end{array}$ & $\begin{array}{l}0.2467 \\
(2.21)^{* * *}\end{array}$ & \begin{tabular}{|l|}
0.1148 \\
$(2.97)^{* * *}$ \\
\end{tabular} & $\begin{array}{l}0.3206 \\
(3.97)^{* * *} \\
\end{array}$ \\
\hline$\overline{\text { Size }_{\mathrm{t}}}$ & $+/-$ & $\begin{array}{l}0.0003 \\
(2.56)^{* * *}\end{array}$ & $\begin{array}{l}0.0003 \\
(1.26)\end{array}$ & \begin{tabular}{|l|}
0.0009 \\
$(7.79)^{* * *}$ \\
\end{tabular} & \begin{tabular}{|l|}
0.0003 \\
$(0.99)$ \\
\end{tabular} \\
\hline Size $_{t} * \mathrm{ROA}_{\mathrm{t}}$ & $+/-$ & $\begin{array}{l}-0.0156 \\
(-1.70)^{*}\end{array}$ & $\begin{array}{l}-0.0147 \\
(-1.03) \\
\end{array}$ & \begin{tabular}{|l|}
-0.0156 \\
$(-1.96)^{* *}$ \\
\end{tabular} & \begin{tabular}{|l|}
0.0044 \\
$(0.27)$ \\
\end{tabular} \\
\hline ADR & $+/-$ & & $\begin{array}{l}-0.0051 \\
(-2.01)^{* *}\end{array}$ & & $\begin{array}{l}-0.0025 \\
(-0.91) \\
\end{array}$ \\
\hline Post*ADR & $+/-$ & & $\begin{array}{l}0.0012 \\
(0.044)\end{array}$ & & $\begin{array}{l}0.0035 \\
(1.09) \\
\end{array}$ \\
\hline $\mathrm{ADR}^{*} \mathrm{ROA}_{\mathrm{t}}$ & $+/-$ & & $\begin{array}{l}0.4034 \\
(2.16)^{* *}\end{array}$ & & $\begin{array}{l}0.2860 \\
(1.52) \\
\end{array}$ \\
\hline $\mathrm{ADR}^{*}$ Post*ROA & - & & $\begin{array}{l}-0.3292 \\
(-1.67)^{* *}\end{array}$ & & $\begin{array}{l}-0.3363 \\
(-1.52)^{*} \\
\end{array}$ \\
\hline $\begin{array}{l}\text { Number of Observations } \\
\text { Adj R-squared }\end{array}$ & & $\begin{array}{l}16,191 \\
0.5889\end{array}$ & $\begin{array}{l}4,401 \\
0.5384\end{array}$ & $\begin{array}{l}16,191 \\
0.5593 \\
\end{array}$ & \begin{tabular}{|l|}
4,401 \\
0.5024 \\
\end{tabular} \\
\hline
\end{tabular}

$*, * *, * * *$ significant at the $10 \%, 5 \%$ and $1 \%$ levels, respectively, based on a one- or two-tailed test, as appropriate.

Variable Definitions:

$\mathrm{ROA}_{\mathrm{t}+\mathrm{n}}$ - Pre-tax Income during year $\mathrm{t}+\mathrm{n}$ scaled by beginning Total Assets;

$\mathrm{EBP}_{\mathrm{t}+1}$ - Pre-tax Income before Loan-Loss Provision during year $\mathrm{t}+1$ scaled by beginning Total Assets;

Post - An indicator variable that equals one in the post-FDICIA period (after 1992), zero otherwise;

$500 \mathrm{M}_{\mathrm{t}}-$ An indicator variable that equals one if Total Assets $>\$ 500$ million (the FDICIA internal control provision threshold) at both the beginning and end of year $t$, zero otherwise;

Size $_{\mathrm{t}} \quad-$ The Log of Total Assets in millions at the beginning of year $\mathrm{t}$;

ADR - An indicator variable that equals one for non-U.S. banks with ADRs, zero otherwise. 
Table 4

Coefficients (t-statistics) from annual benchmark beating probit regressions of the propensity to report small positive earnings changes $\left(\operatorname{Small}{ }_{-} \operatorname{Pos} \Delta_{t}\right)$ for Regulatory and COMPSTAT samples

\begin{tabular}{|c|c|c|c|c|c|}
\hline & & \multicolumn{4}{|c|}{ Small_Pos $\Delta_{t}$} \\
\hline & & \multicolumn{2}{|c|}{ Regulatory } & \multicolumn{2}{|c|}{ COMPUSTAT } \\
\hline Variable & $\begin{array}{l}\text { Predicted } \\
\text { Sign }\end{array}$ & Coefficient & (t-statistic) & Coefficient & (t-statistic) \\
\hline Intercept & $+/-$ & -0.9675 & $(-4.14)^{* * *}$ & -0.7966 & $(-2.17)^{*}$ \\
\hline Post & $+/-$ & 0.0922 & $(2.73)^{* * *}$ & 0.7179 & $(2.53)^{* * *}$ \\
\hline $500 \mathrm{M}_{\mathrm{t}}$ & $+/-$ & 0.0222 & $(0.35)$ & 0.7359 & $(2.56) * * *$ \\
\hline Post* $500 \mathrm{M}_{\mathrm{t}}$ & - & -0.1504 & $(-2.54)^{* * *}$ & -0.6888 & $(-2.39) * * *$ \\
\hline Size $_{t}$ & + & 0.0138 & $(0.85)$ & 0.0204 & $(1.01)$ \\
\hline Public $_{t}$ & + & 0.0561 & $(2.00)^{* *}$ & N/A & N/A \\
\hline Growth $_{\mathrm{t}}$ & $+/-$ & -0.4288 & $(-4.05)^{* * *}$ & -0.5554 & $(-3.72)^{* * *}$ \\
\hline Loans $_{t}$ & + & 0.3600 & $(3.36)^{* * *}$ & N/A & $\mathrm{N} / \mathrm{A}$ \\
\hline NPLoans $_{t}$ & $+/-$ & -27.0583 & $(-12.80)^{* * *}$ & $\mathrm{~N} / \mathrm{A}$ & $\mathrm{N} / \mathrm{A}$ \\
\hline Leverage $_{t}$ & $+/-$ & 1.4001 & $(2.73)^{* * *}$ & 3.0881 & $(2.87)^{* * *}$ \\
\hline$\Delta$ CashFlow $_{\mathrm{t}}$ & $+/-$ & -42.9650 & $(-12.65)^{* * *}$ & -43.6228 & $(-9.22) * * *$ \\
\hline ADR & $+/-$ & & & -0.23201 & $(-0.73)$ \\
\hline Post*ADR & + & & & 0.5622 & $(1.68)^{* *}$ \\
\hline Allow $_{t}$ & $+/-$ & & & -48.2295 & $(-8.89)^{* * *}$ \\
\hline $\begin{array}{l}\text { Number of Observations } \\
\text { Pseudo R-squared }\end{array}$ & & $\begin{array}{l}16,191 \\
0.0314\end{array}$ & & $\begin{array}{l}4,401 \\
0.0616\end{array}$ & \\
\hline
\end{tabular}

$*, * *, * * *$ significant at the $10 \%, 5 \%$ and $1 \%$ levels, respectively, based on a one- or two-tailed test, as appropriate.Variable Definitions:

Small_Pos $\Delta_{t}-$ An indicator variable that equals one if the change in ROA (Pre-tax Income scaled by Total Assets) from year $t-1$ to year $t$ is in the interval between 0 and 0.0008 , zero otherwise;

Post $\quad-$ An indicator variable that equals one in the post-FDICIA period (after 1992), zero otherwise;

$500 \mathrm{M}_{\mathrm{t}}-$ An indicator variable that equals one if the firm has Assets $>\$ 500$ million (the FDICIA internal control provision threshold) at both the beginning and end of year $t$, zero otherwise;

Size $_{t} \quad-$ The Log of Total Assets in millions at the beginning of year $t$;

Public - An indicator variable that equals one if the firm is publicly traded, zero otherwise ;

Growth $_{\mathrm{t}} \quad-$ the growth in Total Assets from the beginning to the end of year $\mathrm{t}$;

Loans $_{\mathrm{t}} \quad-$ Total loans scaled by Total Assets at the beginning of year $t$;

NPLoans $_{\mathrm{t}} \quad$ - Non-performing loans, scaled by Total Assets at beginning of the year $\mathrm{t}$;

Leverage $_{\mathrm{t}} \quad$ - Total Equity divided by Total Assets at beginning of year $\mathrm{t}$;

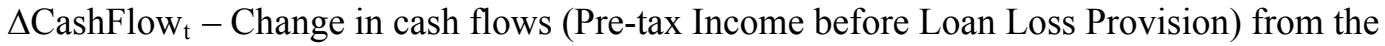
beginning to the end of year $t$ scaled by total assets at the beginning of year $t$;

ADR - An indicator variable that equals one for non-U.S. banks with ADRs, zero otherwise;

Allow $_{\mathrm{t}} \quad-$ Allowance for Loan Losses at the end of year $\mathrm{t}$, scaled by beginning Total Assets. 
Table 5

Coefficients (clustered t-statistics) from annual cross-sectional change in earnings regressions for Regulatory and COMUSTAT samples

\begin{tabular}{|c|c|c|c|c|c|}
\hline & & \multicolumn{2}{|c|}{ Regulatory } & \multicolumn{2}{|c|}{ COMPUSTAT } \\
\hline Variable & Sign & Coefficient & (t-statistic) & Coefficient & (t-statistic) \\
\hline Intercept & $+/-$ & 0.0001 & $(0.30)$ & 0.0009 & $(1.19)$ \\
\hline Post & $++/-$ & -0.0004 & $(-1.95)^{*}$ & -0.0020 & $(-2.54) * *$ \\
\hline $500 \mathrm{M}_{\mathrm{p}}$ & $+/-$ & -0.0007 & $(-2.29)^{* *}$ & -0.0021 & $(-2.50)^{* *}$ \\
\hline Post $^{*} 500 \mathrm{M}_{\mathrm{p}}$ & $+/-$ & 0.0009 & $(2.83) * * *$ & 0.0028 & $(3.25)^{* * *}$ \\
\hline ND & $+/-$ & -0.0009 & $(-3.39)^{* * *}$ & -0.0031 & $(-1.57)$ \\
\hline ND*Post & $+/-$ & 0.0006 & $(2.17)^{* *}$ & 0.0034 & $(1.71)^{*}$ \\
\hline $\mathrm{ND} * 500 \mathrm{M}_{\mathrm{t}}$ & $+/-$ & 0.0001 & $(0.21)$ & 0.0022 & $(1.08)$ \\
\hline ND*Post* $500 \mathrm{M}_{\mathrm{t}}$ & $+/-$ & -0.0001 & $(-0.23)$ & -0.0028 & $(-1.37)$ \\
\hline$\Delta \mathrm{ROA}_{\mathrm{t}}$ & $+/-$ & -0.0441 & $(-0.84)$ & -0.7349 & $(-6.14) * * *$ \\
\hline Post $^{*} \Delta \mathrm{ROA}_{\mathrm{t}}$ & $+/-$ & 0.0230 & $(0.34)$ & 0.9854 & $(6.88)^{* * *}$ \\
\hline $500 \mathrm{M}_{\mathrm{t}} * \Delta \mathrm{ROA}_{\mathrm{t}}$ & $+/-$ & 0.0278 & $(0.26)$ & 0.6599 & $(4.36)^{* * *}$ \\
\hline Post $^{*} 500 \mathrm{M}_{\mathrm{t}} * \Delta \mathrm{ROA}_{\mathrm{t}}$ & $+/-$ & -0.1706 & $(-1.35)$ & -0.9911 & $(-5.41) * * *$ \\
\hline $\mathrm{ND}^{*} \Delta \mathrm{ROA}_{\mathrm{t}}$ & - & -0.2658 & $(-3.71)^{* * *}$ & 0.6850 & $(1.58)$ \\
\hline Post*ND* $\Delta \mathrm{ROA}_{\mathrm{t}}$ & $+/-$ & -0.1762 & $(-1.44)$ & -1.2259 & $(-2.78)^{*}$ \\
\hline $500 \mathrm{M}_{\mathrm{t}} * \mathrm{ND}^{*} \Delta \mathrm{ROA}_{\mathrm{t}}$ & $++/-$ & -0.0885 & $(-0.72)$ & -1.5210 & $(-3.29) * * *$ \\
\hline Post $* 500 \mathrm{M}_{\mathrm{t}} * \mathrm{ND}^{*} \Delta \mathrm{ROA}_{\mathrm{t}}$ & + & 0.3116 & $(1.67)^{* *}$ & 1.4951 & $(3.10)^{* * *}$ \\
\hline Size $_{t}$ & $+/-$ & -0.0000 & $(-0.31)$ & -0.0000 & $(-0.02)$ \\
\hline ADR & $+/-$ & & & 0.0010 & $(1.21)$ \\
\hline Post*ADR & $+/-$ & & & -0.0025 & $(-2.64) * * *$ \\
\hline ADR*ND & $+/-$ & & & -0.0015 & $(-1.09)$ \\
\hline Post*ADR*ND & $+/-$ & & & 0.0022 & $(1.49)$ \\
\hline $\mathrm{ADR}^{*} \Delta \mathrm{ROA}_{\mathrm{t}}$ & $+/-$ & & & -0.9475 & $(-2.74) * * *$ \\
\hline ADR $^{*}$ Post $^{*} \Delta \mathrm{ROA}_{\mathrm{t}}$ & $++/-$ & & & 1.8978 & $(4.43)^{* * *}$ \\
\hline $\mathrm{ADR}^{*} \mathrm{ND}^{*} \Delta \mathrm{ROA}_{\mathrm{t}}$ & $+/-$ & & & 0.08762 & $(1.47)$ \\
\hline $\mathrm{ADR}^{*}$ Post $^{*} \mathrm{ND}^{*} \Delta \mathrm{ROA}_{\mathrm{t}}$ & - & & & -1.1807 & $(-1.71)^{* *}$ \\
\hline $\begin{array}{l}\text { Number of Observations } \\
\text { Adj R-squared }\end{array}$ & & 0.0515 & & 0.1351 & \\
\hline
\end{tabular}

$*, * *, * * *$ significant at the $10 \%, 5 \%$ and $1 \%$ levels, respectively, based on a one- or two-tailed test, as appropriate.

Where:

$\triangle \mathrm{ROA}_{\mathrm{t}+\mathrm{n}}-$ The change in Pre-tax Income during year $\mathrm{t}+\mathrm{n}$ scaled by beginning Total Assets;

Post - An indicator variable that equals one in the post-FDICIA period (after 1992), zero otherwise;

$500 \mathrm{M}_{\mathrm{t}}-$ An indicator variable that equals one if Total Assets $>\$ 500$ million (the FDICIA internal control provision threshold) at both the beginning and end of year $t$, zero otherwise;

$\mathrm{ND}-\mathrm{An}$ indicator variable that equals one if $\Delta \mathrm{ROA}_{\mathrm{t}}$ is negative, zero otherwise;

Size $_{t} \quad-$ The Log of Total Assets in millions at the beginning of year $t$;

ADR - An indicator variable that equals one for non-U.S. banks with ADRs, zero otherwise. 
Table 6

Coefficients (clustered t-statistics) from quarterly cross-sectional charge-off regressions for Regulatory sample

\begin{tabular}{|c|c|c|c|}
\hline & & \multicolumn{2}{|c|}{$\mathrm{CHGOFF}_{\mathrm{q}+4}$} \\
\hline Variable & Sign & Coefficient & (t-statistic) \\
\hline Intercept & $+/-$ & -0.0041 & $(-5.89) * * *$ \\
\hline Post & $+/-$ & -0.0008 & $(-13.95)^{* * *}$ \\
\hline $500 \mathrm{M}_{\mathrm{q}}$ & $+/-$ & -0.0002 & $(-1.32)$ \\
\hline $\mathrm{Q}$ & $+/-$ & 0.0020 & $(4.01)$ \\
\hline Post $* 500 \mathrm{M}_{\mathrm{q}}$ & $+/-$ & -0.0003 & $(-3.24)^{* * *}$ \\
\hline $\operatorname{LLP}_{\mathrm{q}}$ & + & 0.8134 & $(19.15)^{* * *}$ \\
\hline${\text { Post* }{ }^{*} \mathrm{LP}_{\mathrm{q}}}$ & $+/-$ & 0.0598 & $(0.64)$ \\
\hline $500 \mathrm{M}_{\mathrm{q}} * \mathrm{LLP}_{\mathrm{q}}$ & $+/-$ & -0.0829 & $(-1.12)$ \\
\hline Post $^{*} 500 \mathrm{M}_{\mathrm{q}} * \mathrm{LLP}_{\mathrm{q}}$ & + & 0.3132 & $(1.61)^{*}$ \\
\hline $\mathrm{Q}^{*} \mathrm{LLP}_{\mathrm{q}}$ & + & -0.2159 & $(-4.03)^{* * *}$ \\
\hline Post*Q*LLP ${ }_{\mathrm{q}}$ & $+/-$ & 0.1498 & $(1.53)$ \\
\hline $500 \mathrm{M}_{\mathrm{q}} * \mathrm{Q}^{*} \mathrm{LLP}_{\mathrm{q}}$ & $+/-$ & -0.0141 & $(-0.18)$ \\
\hline Post*500M $\mathrm{M}_{\mathrm{q}} * \mathrm{Q} * \mathrm{LLP}_{\mathrm{q}}$ & + & 0.2342 & $(2.16)^{* *}$ \\
\hline Size $_{q}$ & $+/-$ & 0.0005 & $(7.91)^{* * *}$ \\
\hline Q*Size ${ }_{\mathrm{q}}$ & $+/-$ & -0.0002 & $(-5.42)^{* * *}$ \\
\hline Nonacc $_{\mathrm{q}}$ & + & 0.2804 & $(29.35)^{* * *}$ \\
\hline $\mathrm{Q}^{*}$ Nonacc $_{\mathrm{q}}$ & $+/-$ & -0.1692 & $(-22.74)^{* * *}$ \\
\hline $\begin{array}{l}\text { Number of Observations } \\
\text { Adj R-squared }\end{array}$ & & $\begin{array}{l}66,908 \\
0.4472\end{array}$ & \\
\hline
\end{tabular}

$*, * *, * * *$ significant at the $10 \%, 5 \%$ and $1 \%$ levels, respectively, based on a one- or two-tailed test, as appropriate.

Variable Definitions:

$\mathrm{CHGOFF}_{\mathrm{q}+4}-$ Loan charge-offs during period $\mathrm{q}+4$, scaled by Total Assets at the beginning of quarter q+4;

$\mathrm{LLP}_{\mathrm{q}} \quad-$ Loan-loss provision during period q, scaled by Total Assets at the beginning of quarter q;

Post $\quad-$ An indicator variable that equals one in the post-FDICIA period (after 1992), zero otherwise;

Q - An indicator variable that equals one in the first, second, or third fiscal quarter, zero otherwise;

$500 \mathrm{M}_{\mathrm{q}}-$ An indicator variable that equals one if Total Assets $>\$ 500$ million (the FDICIA internal control provision threshold) at both the beginning and end of quarter $\mathrm{q}$, zero otherwise;

Size $_{\mathrm{q}} \quad-$ The Log of Total Assets in millions at the beginning of quarter q;

Nonacc $_{\mathrm{q}} \quad-$ non-performing at quarter q, scaled by Total Assets at the beginning of quarter q.. 
Table 7

Coefficients (clustered t-statistics) from quarterly cross-sectional earnings persistence and predictability of cash flow regressions for Regulatory sample

\begin{tabular}{|c|c|c|c|c|c|}
\hline & & \multicolumn{2}{|l|}{$\mathrm{ROA}_{\mathrm{q}+\mathrm{n}}$} & \multicolumn{2}{|c|}{$\mathrm{EBP}_{\mathrm{q}+4}$} \\
\hline Variable & Sign & Coefficient & (t-statistic) & Coefficient & (t-statistic) \\
\hline Intercept & $+/-$ & 0.0002 & $(0.65)$ & 0.0003 & $(0.95)$ \\
\hline Post & $+/-$ & 0.0005 & $(5.27) * * *$ & -0.0003 & $(-2.65) * * *$ \\
\hline $500 \mathrm{M}_{\mathrm{q}}$ & $+/-$ & -0.0002 & $(-2.08) * *$ & -0.0001 & $(-1.39)$ \\
\hline Post*500M & $+/-$ & 0.0005 & $(2.33)^{* *}$ & -0.0001 & $(-0.56)$ \\
\hline Q & & 0.0004 & $(1.13)$ & -0.0000 & $(-0.02)$ \\
\hline $\mathrm{ROA}_{\mathrm{q}}$ & + & 0.3537 & $(15.76)^{* * *}$ & 0.2182 & $(15.76)^{* * *}$ \\
\hline Post*ROA & $+/-$ & 0.0665 & $(1.84)^{*}$ & 0.1252 & $(4.20)^{* * *}$ \\
\hline $500 \mathrm{M}_{\mathrm{q}} * \mathrm{ROA}_{\mathrm{q}}$ & $+/-$ & -0.0237 & $(-0.73)$ & -0.0373 & $(-1.68)^{*}$ \\
\hline Post*500M $\mathrm{M}_{\mathrm{q}} * \mathrm{ROA}_{\mathrm{q}}$ & + & -0.0407 & $(-0.76)$ & 0.0231 & $(0.49)$ \\
\hline Q*ROA & + & 0.1321 & $(4.62) * * *$ & 0.1325 & $(5.83) * * *$ \\
\hline Post*Q*ROA & $+/-$ & -0.0196 & $(-0.68)$ & 0.0176 & $(0.74)$ \\
\hline $500 \mathrm{M}_{\mathrm{q}} * \mathrm{Q} * \mathrm{ROA}_{\mathrm{q}}$ & $+/-$ & -0.0356 & $(-0.92)$ & -0.0219 & $(-0.78)$ \\
\hline Post $* 500 \mathrm{M}_{\mathrm{q}} * \mathrm{Q} * \mathrm{ROA}_{\mathrm{q}}$ & + & 0.0562 & $(1.34)^{*}$ & 0.0618 & $(1.91)^{* *}$ \\
\hline Size $_{q}$ & $+/-$ & 0.0001 & $(2.82) * * *$ & 0.0002 & $(8.99) * * *$ \\
\hline Q*Size & $+/-$ & -0.000 & $(-0.73)$ & -0.0000 & $(-0.54)$ \\
\hline $\begin{array}{l}\text { Number of Observations } \\
\text { Adj R-squared }\end{array}$ & & $\begin{array}{l}67,076 \\
0.2683 \\
\end{array}$ & & $\begin{array}{l}67,076 \\
0.5593 \\
\end{array}$ & \\
\hline
\end{tabular}

$*, * *, * * *$ significant at the $10 \%, 5 \%$ and $1 \%$ levels, respectively, based on a one- or two-tailed test, as appropriate.

Variable Definitions:

$\mathrm{ROA}_{\mathrm{q}+\mathrm{n}}-$ Pre-tax Income during quarter $\mathrm{q}+\mathrm{n}$ scaled by beginning of the quarter Total Assets;

$\mathrm{EBP}_{\mathrm{q}+4}$ - Pre-tax Income before Loan Loss Provision during quarter $\mathrm{q}+4$ scaled by beginning of the quarter Total Assets;

Post - An indicator variable that equals one in the post-FDICIA period (after 1992), zero otherwise;

Q -- An indicator variable that equals one in the first, second, or third fiscal quarter, zero otherwise;

$500 \mathrm{M}_{\mathrm{q}}-$ An indicator variable that equals one if the firm has Assets $>\$ 500$ million (the FDICIA internal control provision threshold) at both the beginning and end of quarter q, zero otherwise;

Size $_{\mathrm{q}} \quad-$ The natural log of Total Assets in millions at the beginning of quarter q;

ADR - An indicator variable that equals one for non-U.S. banks with ADRs, zero otherwise. 
Figure 1 - FDICIA Reporting Requirements and their relationship to SOX Reporting Requirements

\begin{tabular}{|l|c|c|}
\hline & FDICIA & SOX \\
\hline Independent Audit Committee & $\sqrt{36}$ & $\sqrt{301}$ \\
\hline Management Responsibility & $\sqrt{36}$ & $\sqrt{302}$ \\
\hline Report on effectiveness of IC & $\sqrt{36}$ & $\sqrt{404}$ \\
\hline Auditor attestation of management report & $\sqrt{36}$ & $\sqrt{404}$ \\
\hline Auditor attestation of IC's effectiveness & N/A & $\sqrt{404}$ \\
\hline
\end{tabular}


Figure 2 - Ratio of other expenses to assets for effected $(>\$ 500 \mathrm{M})$ and unaffected $(<\$ 500 \mathrm{M})$ banks

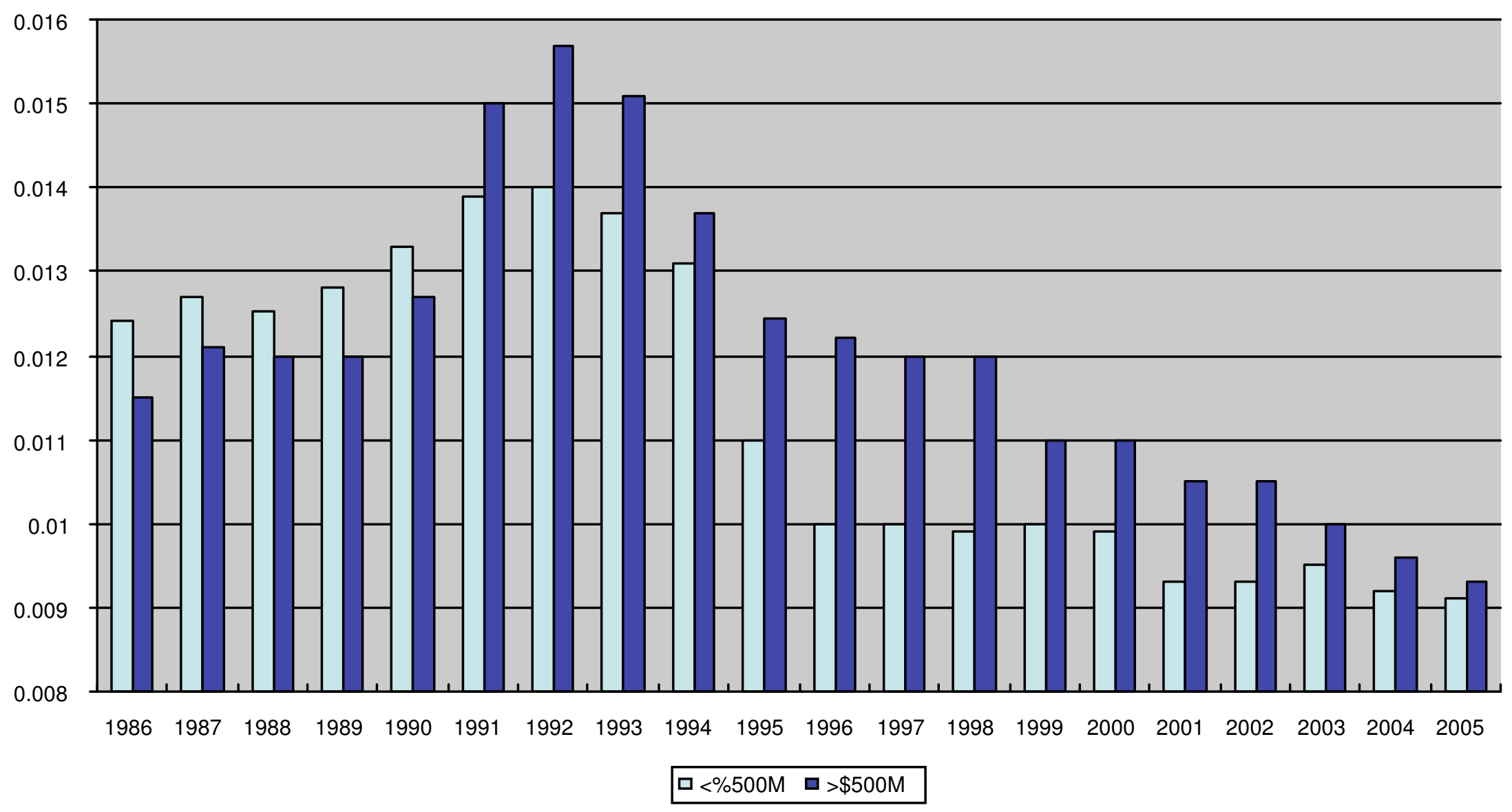

